
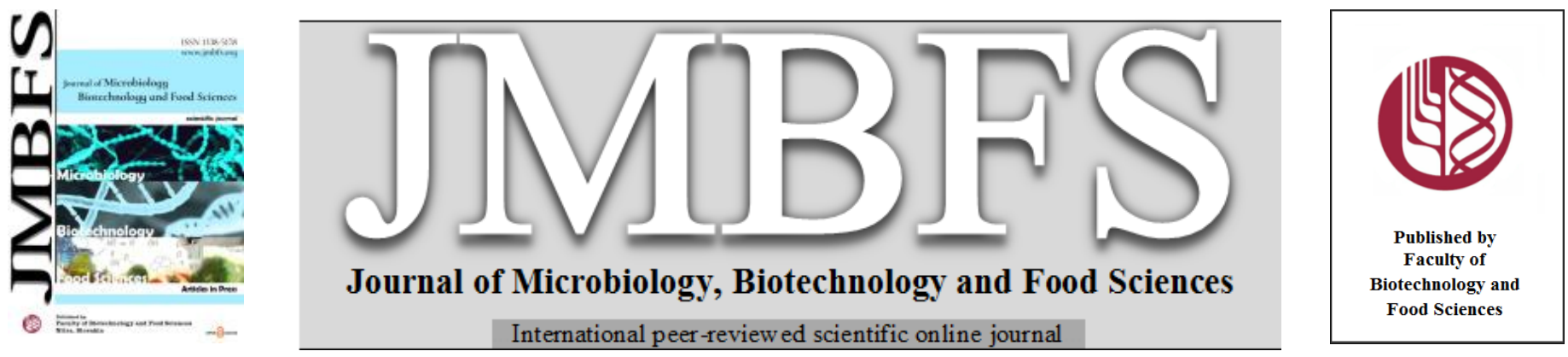

\title{
FERMENTABLE OLIGOSACCHARIDES, DISACCHARIDES, MONOSACCHARIDES AND POLYOLS AND THEIR ROLE IN FOOD DIGESTION
}

\author{
Dana Urminská ${ }^{* 1}$, Nora Haring ${ }^{1}$, Vladimir Fábry ${ }^{1}$, Jana Urminská2
}

Address(es): doc. RNDr. Dana Urminská, CSc.

${ }^{1}$ Slovak University of Agriculture in Nitra, Faculty of Biotechnology and Food Sciences, Institute of Biotechnology, Trieda Andreja Hlinku 2, 94901 Nitra, Slovakia. ${ }^{2}$ Slovak University of Agriculture in Nitra, Faculty of Biotechnology and Food Sciences, Institute of Food Processing, Trieda Andreja Hlinku 2, 94901 Nitra, Slovakia.

*Corresponding author: dana.urminska@uniag.sk

https://doi.org/10.55251/jmbfs.5521

\section{ARTICLE INFO}

Received 8. 11. 2021

Revised 20. 1. 2022

Accepted 20. 1.2022

Published 1. 2. 2022

Review

OPEN $\partial_{\text {ACCESS }}$

\begin{abstract}
Oligosaccharides containing fructose (fructans, inulin), galactose (galactans, stachyose, raffinose), disaccharides enclosing galactose (lactose), monosaccharides and mixtures of monosaccharides encompassing fructose (fruit sugar, honey) and saccharide polyols (mannitol, malbitol, sorbitol), are considered as safe to be consumed and beneficial to health. Gradually, however, their presence in the human diet reaches amounts that are indigestible by the small intestine, causing an osmotic load on the intestinal lumen. Subsequently, they pass into the large intestine, where they are fermented by intestinal bacteria to undesirable products such as gaseous carbon dioxide, hydrogen, methane, sulfane, and short chain fatty acids. Indigestible fermentable oligosaccharides, disaccharides, monosaccharides, and polyols may cause undesirable symptoms such as an increased flatulence, bloating, abdominal pain, alterations to the intestinal physiology, cessation of peristalsis, or diarrhea, which are manifested by a wide array of diseases of the gastrointestinal tract, such as the irritable bowel syndrome or small intestinal bacterial overgrowth. Fruits, vegetables, dairy products, legumes, some cereals, as well as honey or various sweeteners are among the most common food sources of these carbohydrates.
\end{abstract}

Keywords: FODMAP, irritable bowel syndrome, fructane, galactane

\section{INTRODUCTION}

Over the recent decades, human nutrition has been characterized by a shift from conventional foods to new types of foods, functional foods, or foods with a positive effect on the health and vitality. Prebiotics are also among healthy food ingredients. These are defined as substances of a carbohydrate nature that the human body cannot digest or degrades them only partially, while on the other hand, they serve as good substrates for the intestinal microorganisms. This heterogenous group includes the so-called fermentable oligo-, di-, mono- and saccharide polyols, abbreviated FODMAP. Their high intake may exhibit a negative effect on the human health, since the intestinal microflora produces various organic acids and gaseous substances in the large intestine, which may cause discomfort in the gastrointestinal tract. Historically, lactose, fructose and sorbitol have been the first to be associated with digestive problems. Gradually, and especially in connection with the development of the irritable bowel syndrome (IBS), the oligosaccharides galactans and fructans have also attracted the attention of the scientists and physicians.

The human digestive tract contains beneficial microorganisms that protect the body from pathogenic microorganisms and play an important role in the prevention of inflammatory diseases by stimulating the immune system. Through their metabolism, intestinal microorganisms help to break down and utilize food components that the human body cannot metabolize on its own. They also synthesize a variety of micronutrients, such as vitamins K, B2, B9 and B12, A, D and $\mathrm{K}$ (Tojo et al., 2014; Morrison and Preston, 2016). Some intestinal bacteria are producers of short-chain fatty acids, which are a major source of nutrients for the colon cells. They support the formation of a sufficiently resistant intestinal barrier that prevents a possible entry of harmful substances, viruses, or bacteria, reducing the risk of inflammatory or tumorous processes. In an effort to support these defense mechanisms, an excessive consumption of fiber, including fructooligosaccharides (such as inulin) or galactooligosaccharides (such as pectins and various gums, cellulose and hemicelluloses) has been reported. These food components are not hydrolyzed by the digestive enzymes but act as suitable substrates for microbial fermentation in lower parts of the digestive tract. Consequently, an intensive development of microcenosis, called bacterial overgrowth may occur, leading to the development of IBS, dysbiosis, disruption of intestinal peristalsis, accompanied by water and nutrient malabsorption.

\section{Characteristics and significance of intestinal microcenosis}

The intestinal microcenosis is very rich in various types of microorganisms, dominated by bacteria representing the genera Ruminococci, Bifidobacteria, Proteobacteria, Lactobacilli and Streptococci (O'Hara and Shanahan, 2006). In addition, Actinobacteria, Verrucobacteria and Fusobacteria have been identified, as well as Archaea and eukaryotic microbioses (Eckburg et al., 2005; Scanlan and Marchesi, 2008). The human intestinal microcenosis may include approximately 1150 microbial species, out of which about 160 species are present in every individual (Qin et al., 2010; Orth et al., 2011; Tilg and Kaser, 2011). However, up to $80 \%$ of bacterial species of human origin cannot be cultured in vitro (Eckburg et al., 2005).

Most of the bacteria present in human intestines are non-sporing anaerobes, out of which Bacteroides sp. and Bifidobacterium sp., Eubacterium sp., Clostridium sp., Lactobacillus sp., Fusobacterium sp. and various gram-positive cocci are the most predominant. A minor portion of bacteria is represented by Enterococcus sp., Enterobacteriaceae sp. and sulfate-lowering bacteria. Nevertheless, there are approximately 300 to 500 different bacterial species, the presence of which in the gut varies from individual to individual (Guarner and Malagelada, 2003; Iannitti and Palmieri, 2010). Methanogenic Archaea are also present in the human gastrointestinal tract, whose interactions with the host may be beneficial as well as harmful (Macario and Macario, 2009). Archaea are typical representatives of anaerobic intestinal microbiota (Million et al., 2016) and are already present in a child's digestive system (Wampach et al., 2017). These microorganisms have been of interest for several decades. Methanobrevibacter smithii, Methanosphaera stadtmanae (Miller and Wolin, 1983), members of the order Methanomassiliicoccales (Mihajlovski et al., 2008) have been isolated from the intestinal contents of adults. Methanomassiliicoccus luminyensis, Methanomethylophilus alvus and Methanomassiliicoccus intestinalis have been identified as well (Borrel et al., 2012; Gaci et al., 2014).

An imbalance between beneficial and harmful microorganisms defined as dysbiosis, in which pathogenic bacteria predominate over commensal 
microorganisms, leads to a dysfunction of the large intestine. Possible causes of these changes include the use of antibiotics, laxative abuse, excessive consumption of processed foods and diseases such as cancer, acquired immune deficiency syndrome or diverticulitis (Cani and Delzenne, 2007).

The body naturally defends itself against dysbiosis by the fact that the intestina cells and beneficial microorganisms secrete chemicals that modulate the mucosa immunity and a subsequent inflammatory response as a strategy to combat various pathogens. For example, Bacteroides fragilis produces immunomodulatory and pro-inflammatory polysaccharides, such as polysaccharide A. This polysaccharide can induce a cascade of processes that leads to the production of interleukin IL-10 and promotes the colonization of Bacteriodes fragilis while at the same time limiting the intestinal colonization by competing microorganisms, including Helicobacter hepatis which causes colitis. Based on experiments in animal models, several authors have reported that oral administration of this polysaccharide may reduce the risk of colitis (Mazmanian et al., 2008; Round et al., 2011; Mousa et al., 2017). Another example of a bacterial species that utilizes this strategy is Lactobacillus plantarum, which secretes amino acid derivatives that reduce the levels of the pro-inflammatory cytokine interferon INF- $\gamma$ (Zvanych et al., 2014). Bifidobacterium longum and Bacteroides thetaiotaomicron are also present in the gastrointestinal tract, being able to metabolize arachidonic acid and produce prostaglandins and leukotrienes that affect the immune response (Eberhard $\boldsymbol{e t}$ al., 2002).

Intestinal microorganisms produce bacteriocins that have a microbistatic or microbicidal effect. For example, the metabolic product of Lactobacillus gasser is gassericin $\mathrm{B}$, which exhibits antibacterial activity against Listeria monocytogenes, Staphylococcus aureus and Bacillus cereus. Lactobacillus reuteri produces reuterin, which has the ability to protect the host from pathological strains of Escherichia coli (Mousa et al., 2017). Lactobacillus plantrum secretes lantipeptides called plantaricins that act against gram-positive bacteria such as Streptococcus thermophilus and Enterococcus fecalis (Turner et al., 2004). Pediococcus produces pediocins that are effective against Listeria sp. (Papagianni and Anastasiadou, 2009), while thuricin CD from Bacillus thurigiensis is effective against Clostridium difficile and Listeria monocytogenes. In the meantime, Bacillus subtilis produces amicoumacin A, which exhibits an antibiotic and anti-inflammatory activity against Helicobacter pylori (Pinchuk et al., 2020; Rea et al., 2010).

Food and nutrition have a significant effect on the composition and activity of the human gastrointestinal microcenosis (Salonen et al., 2014; Sonnenburg and Bäckhed, 2016). Several studies have revealed links between the composition of the intestinal microcenosis and diseases of the body. The intestinal microcenosis may also significantly interfere with specific drug therapies, bringing attention of the pharmaceutical industry to these microorganisms (Routy et al., 2018). The diagnostic approach is gradually changing, which also includes the identification of bacteria in the patient's gut (Kåhrströmn et al., 2016; Flemer et al., 2018).

\section{Bacterial overgrowth}

The upper gastrointestinal tract, comprising the stomach, duodenum, and lumbar region, is sparsely populated by microorganisms due to the microbicidal gastric acid barrier (Mackie et al., 1999). Acid-resistant Helicobacter pylori and lactobacilli dominate this region of the gastrointestinal system (Ghoshal $\boldsymbol{e t}$ al. 2012). The distal part of the small intestine and the large intestine are inhabited by a larger number of microorganisms, such as coliform, gram-negative nonsporulating bacilli (Mackie et al., 1999).

A proper intestinal microcenosis defined as eubiosis, is essential for the health of the body. Abnormalities such as dysbiosis, including a quantitative increase in the number of bacteria, such as small intestinal bacterial overgrowth (SIBO) or changes in the location of bacteria during which colon bacteria are found in the small intestine, cause various diseases (Prakash et al., 2011; Ghoshal and Srivastava, 2014; Nagao-Kitamoto et al., 2016). Bacterial overgrowth of the small intestine is defined as an excessive increase in the number of bacteria above $10^{5}$ colony forming units (CFU) in $1 \mathrm{~mL}$ of jejunal aspirate (Ghoshal and Srivastava, 2014; Ghoshal et al., 2012). Several authors consider overgrowth a condition in which SIBO is $>10^{3} \mathrm{CFU} / \mathrm{mL}$ jejunal aspirate. Determining this number is important in demonstrating the presence of coliform bacteria or in the diagnosis of IBS (Khoshini et al., 2008; Ghoshal et al., 2012). SIBO causes gastrointestinal dysfunction by several mechanisms, including a prolonged inflammation, activation of the immune system, changes in the intestinal peristalsis and permeability, deconjugation of bile acid salts, secondary lactase deficiency, malabsorption of water and nutrients with an increasing osmotic load on the luminal content of the intestine (Pimentel et al., 2004; Ghoshal et al., 2012; Ghoshal and Srivastava, 2014). In contrast to healthy individuals, the smal intestine of subjects affected by SIBO contains bacteria of the colon, including gram-negative aerobes and anaerobes (e.g. Escherichia coli, Enterococcus spp. Proteus mirabilis) (Bouhnik et al., 1999; Sachdev and Pimentel, 2013) which ferment carbohydrates with an intensive production of gases causing symptoms such as bloating, abdominal distension, pain, and cramps (Posserud et al., 2007; Sachdev and Pimentel, 2013). The severity of the difficulties depends on the amount of carbohydrates consumed (Shepherd et al., 2008).

\section{Characteristics of FODMAP}

Fermentable oligosaccharides, disaccharides, monosaccharides and polyols are short chain carbohydrates prevalent in foods such as fruits, vegetables, dairy products, cereals and legumes. They are also found in processed foods to which these raw materials have been added. From the point of view of human nutrition, the most frequently consumed FODMAP monosaccharides are fructose, glucose, and galactose, while the most eaten FODMAP disaccharides include sucrose, lactose, verbaskose, maltose and isomaltose. Plant food is also rich in the trisaccharide raffinose and the tetrasaccharide stachyose. The polysaccharides comprise various long fructans, galactans and galactomannans, agar, carrageenan, laminaran, hemicelluloses and cellulose (Qi and Tester, 2019). Fermentable polyalcohols are represented by sorbitol, mannitol, maltitol, and xylitol (Tuck et al., 2014) (Tab. 1).

Table 1 Examples of fermentable di-, oligo-, polysaccharides and polyols

\begin{tabular}{|c|c|c|c|c|}
\hline FODMAP & Name & Other name & Composition & Chemical formula \\
\hline \multirow{7}{*}{ monosaccharides } & \multirow{3}{*}{ glucose } & grape & D-glucopyranose & $\mathrm{C}_{6} \mathrm{H}_{12} \mathrm{O}_{6}$ \\
\hline & & sugar & D-glucopyranose & $\mathrm{C}_{6} \mathrm{H}_{12} \mathrm{O}_{7}$ \\
\hline & & dextrose & D-glucopyranose & $\mathrm{C}_{6} \mathrm{H}_{12} \mathrm{O}_{8}$ \\
\hline & fructose & levulose & D-fructofuranose & $\mathrm{C}_{6} \mathrm{H}_{12} \mathrm{O}_{7}$ \\
\hline & galactose & cerebrose & D-galactopyranose & $\mathrm{C}_{6} \mathrm{H}_{12} \mathrm{O}_{6}$ \\
\hline & mannose & carubinose & D-mannopyranose / D-mannofuranose & $\mathrm{C}_{6} \mathrm{H}_{12} \mathrm{O}_{6}$ \\
\hline & ramnose & isodulcit & 6-deoxy-L-mannose & $\mathrm{C}_{6} \mathrm{H}_{12} \mathrm{O}_{5}$ \\
\hline \multirow{6}{*}{ disaccharides } & saccharose & sugar & D-glucose $(1 \rightarrow 2)$ D-fructose & $\mathrm{C}_{12} \mathrm{H}_{22} \mathrm{O}_{11}$ \\
\hline & lactose & milk sugar & D-galactose $(1 \rightarrow 4) \mathrm{D}$-glucose & $\mathrm{C}_{12} \mathrm{H}_{22} \mathrm{O}_{11}$ \\
\hline & maltose & malt sugar & D-glucose $(1 \rightarrow 4)$ D-glucose & $\mathrm{C}_{12} \mathrm{H}_{22} \mathrm{O}_{11}$ \\
\hline & isomaltose & palatinose & D-glucose $(1 \rightarrow 6)$ D-glucose & $\mathrm{C}_{12} \mathrm{H}_{22} \mathrm{O}_{11}$ \\
\hline & trehalose & & D-glucose $(1 \rightarrow 1)$ D-glucose & $\mathrm{C}_{12} \mathrm{H}_{22} \mathrm{O}_{11}$ \\
\hline & cellobiose & & D-glucose $(1 \rightarrow 4)$ D-glucose & $\mathrm{C}_{12} \mathrm{H}_{22} \mathrm{O}_{11}$ \\
\hline \multirow{2}{*}{ trisaccharides } & raffinose & melitose & D-galactose $(1 \rightarrow 6) \mathrm{D}$-glucose $(1 \rightarrow 2) \mathrm{D}$-fructose & $\mathrm{C}_{18} \mathrm{H}_{32} \mathrm{O}_{16}$ \\
\hline & kestose & & D-fructose $(2 \rightarrow 1)$ D-fructose $(2 \rightarrow 1)$ D-glucose & $\mathrm{C}_{18} \mathrm{H}_{32} \mathrm{O}_{16}$ \\
\hline pentasaccharides & verbascose & & D-galactose $(1 \rightarrow 6)$-[D-galactose $]_{2}(1 \rightarrow 6) \mathrm{D}$-glucose $(1 \rightarrow 2) \mathrm{D}$-fructose & $\mathrm{C}_{30} \mathrm{H}_{52} \mathrm{O}_{26}$ \\
\hline \multirow{3}{*}{ polysaccharides } & agar & & {$[\text { D-galactose }(1 \rightarrow 3) D \text {-galactose }]_{\mathrm{n}}(1 \rightarrow 4) /[3,6 \text {-anhydro-L-galactose }]_{\mathrm{m}}$} & \\
\hline & carrageenan & & $\begin{array}{c}\text { sulfated or nonsulfated }[\mathrm{D} \text {-galactose }(1 \rightarrow 3) \mathrm{D} \text {-galactose }]_{\mathrm{n}}(1 \rightarrow 4)[3,6- \\
\text { anhydro-L-galactose }]_{\mathrm{m}}\end{array}$ & \\
\hline & laminaran & laminarin & D-glucose linear polysaccharide with $(1 \rightarrow 3):(1 \rightarrow 6)$ ratio of $3: 1$ & $\left(\mathrm{C}_{6} \mathrm{H}_{10} \mathrm{O}_{5}\right)_{\mathrm{x}}$ \\
\hline \multirow{4}{*}{ polyols } & mannitol & mannite & hexane- $1,2,3,4,5,6$-hexol & $\mathrm{C}_{6} \mathrm{H}_{14} \mathrm{O}_{6}$ \\
\hline & sorbitol & D-glucitol & hexane-1,2,3,4,5,6-hexol / izomer of mannitol & $\mathrm{C}_{6} \mathrm{H}_{14} \mathrm{O}_{6}$ \\
\hline & xylitol & xylite & 1,2,3,4,5-pentahydroxypentane & $\mathrm{C}_{5} \mathrm{H}_{12} \mathrm{O}_{5}$ \\
\hline & maltitol & & D-glucopyranosyl-D-glucitol & $\mathrm{C}_{12} \mathrm{H}_{24} \mathrm{O}_{11}$ \\
\hline
\end{tabular}




\section{Negative effects of FODMAP on the human digestive tract}

Currently, the effects of malabsorption and intolerance to carbohydrates are increasingly evident in the human population. Their exact prevalence is unknown. This intolerance often leads to various, as yet unexplained difficulties in the gastrointestinal tract, such as flatulence, gas production, pain, distension, nausea, and diarrhea. Patients with such gastrointestinal symptoms are often subjected to an examination including endoscopy, blood tests and stool collection to determine a specific disease. However, the test results may be negative, in which case the gastrointestinal disorders may include IBS (Fedewa and Rao, 2014). One of the causes of IBS may lie in a high intake of FODMAP. It has been found that in developed countries, the disease affects one in five adults, with a higher prevalence in women.

Lactose has been described as the first carbohydrate associated with indigestion. A strict elimination of lactose from the diet, small bowel biopsy alongside with the determination of lactase activity and hydrogen in the breath have become the basis for the recognition of lactose malabsorption and intolerance (Gibson, 2017). While lactose-free diet has been very successful in some patients, it did not completely eliminate the undesirable and painful symptoms after consuming carbohydrates in most subjects (Vernia et al., 1995). In the 1990s, suggestions began to emerge that not only lactose but also fructose and sorbitol may play an important role in the development of IBS, since their elimination from the diet has led to a stabilization of digestive issues (Rumessen and Gudmand-Høyer, 1988; Nelis et al., 1990; Symons et al., 1992).

Nevertheless, foods do not only contain these carbohydrates in their free form, but also as part of oligosaccharides and polysaccharides. Therefore, fructooligosaccharides (fructans), galactooligosaccharides (galactans) and carbohydrate polyols, which are not completely absorbed in the gastrointestinal tract, have been included among the food components that can cause typical digestive problems.

Irritable bowel syndrome is characterized by abdominal pain, an unpleasan bloating, flatulence, and changes in the intestinal microcenosis, which may result in diarrhea or constipation. Mucus often occurs in the stool (Spiller and Garsed, 2009). Triggers of this syndrome are foods containing FODMAP. The condition is worsened especially by those containing spices, chocolate, beans, cabbage, fermented vegetables, and fruits. Changes in the intestinal microbiota or dysbiosis after ingestion of antibiotics or following gastrointestinal viral, bacterial, and parasitic infections may also contribute to the pathogenesis of IBS. Genetic predisposition also plays a role in IBS, since a family history is found in approximately 30\% of patients (Spiller and Garsed, 2009). Recurrent abdomina pain is associated with advanced IBS and comes along with at least two of the following symptoms: defecation accompanied by pain, changes in the stool frequency, and alterations in the stool pattern. These symptoms reduce the quality of life, which is why it is necessary to pay attention to FODMAP, so that these can be identified in the diet and subsequently excluded in affected patients. In this sense, several authors point to the role of the intestinal microcenosis and subsequent changes in the gut microbial diversity (Lacy and Patel, 2017; Losurdo et al., 2018).

\section{Fermentable monosaccharides}

Monosaccharides are absorbed from food in the human small intestine, which contains specific monosaccharide transporters (Röder et al., 2014). According to Wright et al. (2003) the majority of carbohydrate uptake is mediated by specific carbohydrate-transporting proteins through the basolateral membranes of small intestinal enterocytes. These transporters are in particular glucose transporters (GLUT), which transport monosaccharides as follows: fructose is facilitated by diffusion through GLUT2 and GLUT5, galactose is delivered by co-transport with sodium ions via SGLT1 or by facilitated diffusion via GLUT2, while glucose alone is transported via sodium glucotransport and GLUT2 (Le Gall et al., 2007). In some individuals, the availability of the GLUT5 transporter is limited in the presence of glucose, leading to fructose malabsorption (Riby et al., 1993). This condition is typical for patients with IBS, occurring in up to $45 \%$ of all cases.

\section{Fruit sugar - fructose}

Fructose is a simple carbohydrate present in fruits and honey; however, it is also a major ingredient in two of the most commonly used food sweeteners, sucrose (fructose and glucose disaccharide) and syrup made from corn starch and considered a condiment with a high fructose content (HFCS, high fructose corn syrup). At present, the intake of fructose as an added sugar is close to $15 \%$ of the total energy intake from food in families with higher incomes, especially among younger individuals (Lanaspa et al., 2014; Yracheta et al., 2015) due to a high consumption of soft drinks. While sucrose-containing beverages have the same amount of glucose and fructose, HFCS-containing beverages have a fructose and glucose content oscillating from 55:45 to 65:35 (Ventura et al., 2012). Fructose is absorbed in the small intestine by specific transporters expressed in both the apical and basolateral membranes of enterocytes (Manolescu et al., 2007). After absorption, fructose is primarily metabolized in the liver (Schalkwijk et al., 2004). Excess fructose passes into the large intestine, where it becomes a fermentable substrate for microorganisms. High fructose intake has been reported to alter the composition of microcenosis, leading to a reduced bacterial diversity and changes in the expression patterns of genes involved in specific metabolic pathways (Payne et al., 2012).

Fructose is considered to be one of the most important fermentable carbohydrates within the FODMAP group (Chumpitazi and Shulman, 2016; Giorgio et al., 2016). Any fructose not absorbed by the small intestine is fermented by colon bacteria producing short-chain fatty acids and gases, such as hydrogen and carbon dioxide, which may cause bloating, abdominal discomfort, and/or diarrhea in some individuals (Skoog et al., 2004; Shepherd and Gibson, 2006). Hydrogen produced during the fermentation process is partially absorbed into the bloodstream and enters the lungs, allowing it to be detected in the exhaled air. This process is used in the diagnosis of fructose malabsorption, and is called the hydrogen breath test (Gomara $\boldsymbol{e t}$ al., 2008). Fructose intolerance, manifested by abdominal pain, flatulence, diarrhea, nausea, and vomiting, has also been diagnosed in some patients with indigestion (Gomara et al., 2008; Medeiros et al., 2012).

\section{Honey - a mixture of monosaccharides containing fructose}

Honey is a natural sweet substance produced by Apis mellifera from the nectar of plants, secretions from live parts of plants or secretions from insects sucking on live parts of plants, which bees collect, transform, and enrich with their own specific substances, thicken, store and leave in honeycombs to mature. The mos commercially important types of honey are nectar and honeydew (Kaškoniene and Venskutonis, 2010). Honey is primarily a sweetener, but it is also consumed as a prebiotic as it contains oligosaccharides that can promote the growth of lactobacilli and bifidobacteria. However, this prebiotic potential is not as significant in comparison with the consumption of pure fructooligosaccharides (Sanz et al., 2005).

Honey is an oversaturated solution of sugars, particularly fructose and glucose, which contains several minor components (Viuda-Martos et al., 2008). Among the disaccharides sucrose and maltose make up 5 to $9 \%$, followed by oligosaccharides, which represent 3 to $10 \%$ depending on the type of honey. A more detailed overview of carbohydrates found naturally in honey is provided in Table 2 (Astwood et al., 1998; Viuda-Martos et al., 2008). Honey contains carbohydrates, which are included in FODMAP, particularly fructose and fructooligosaccharides inulin and oligofructose that promote the growth of lactic acid bacteria from the genera Lactobacillus and Bifidobacterium. These bacteria are considered to be probiotic bacteria with an intensive saccharolytic metabolism (Gibson and Roberfroid, 1995; Gibson and Shepherd, 2010). Nevertheless, an increased number of these bacteria in the colon may result in the production of short-chain gases and fatty acids due to their anaerobic fermentation metabolism (Roberfroid et al., 2010; Flint et al., 2012).

Table 2 Average carbohydrate content in honey (Doner, 1977; Bogdanov et al., 2007)

\begin{tabular}{lccc}
\hline Carbohydrate & Nectar honey & $\begin{array}{c}\text { Homeydew } \\
\text { honey }\end{array}$ \\
\hline $\begin{array}{l}\text { monosaccharides, } \\
\%\end{array}$ & fructose & 38.2 & 31.8 \\
\cline { 2 - 4 } disaccharides, $\%$ & glucose & 31.3 & 26.1 \\
\cline { 2 - 4 } & $\begin{array}{c}\text { maccharose } \\
\text { others }\end{array}$ & $0.7-1.31$ & $0.5-0.8$ \\
\hline trisaccharides, $\%$ & melezitose & $<-7.31$ & $4-8.8$ \\
\cline { 2 - 4 } $\begin{array}{l}\text { oligosaccharides, } \\
\%\end{array}$ & non specific & 3.1 & 4.0 \\
\hline
\end{tabular}

\section{Fermentation of fructose}

Fructose currently accounts for $1 / 6$ to $1 / 3$ of the total carbohydrate intake (Bhagan and Ha, 2011). It is the sweetest monosaccharide with a low glycemic index (Hedayat and Lapraz, 2019). Fructose is absorbed by the small intestinal epithelial cells (Douard and Ferraris, 2012) through two mechanisms: if glucose and fructose are absorbed in an equimolar ratio by simultaneous transport with glucose (GLUT-2 transporter), in case of excess fructose the molecule is absorbed into the apical membrane of the enterocyte specific carrier using GLUT-5. The concentration of fructose is higher in the lumen than in the epithelium of the cells, which allows the molecule to use a concentration gradient and thus pass with the help of the transport proteins; however, this mechanism has a low capacity.

The first step in the metabolism of fructose lies in the formation of fructose-1phosphate, which is cleaved to form two tricarbon molecules, namely glyceraldehyde and dihydroxyacetone phosphate (Fig. 1). These trioses will form pyruvate (further reduced to lactate), glycerol and, glucose in the case of dihydroxyacetone phosphate (Geidl-Flueck et al., 2021). 


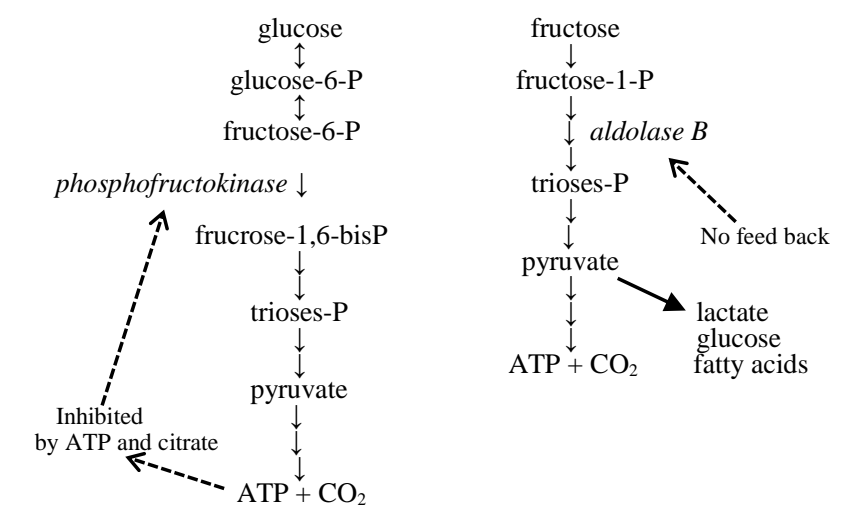

Figure 1 Metabolism of glucose and fructose in small bowel enterocytes, hepatocytes, and proximal tubule cells of the kidneys (Geidl-Flueck $\boldsymbol{e t}$ al., 2021)

Approximately $3 \%$ of fructose is used for the synthesis of triacylglycerols, ketone compounds and sorbitol (Macdonald, 2003).

Intestinal microorganisms involve fructose in their metabolism through glycolysis. As such, a mixed acid fermentation is typical for the genera Citrobacter, Escherichia, Proteus, Salmonella, Shigella, Yersinia and Vibrio and several Aeromonas species (Fig. 2). Some of these microorganisms are representative of a normal intestinal microcenosis in mammals, while others are pathogens (Ciani $\boldsymbol{e}$ al., 2013). They produce lactic acid, formic acid, succinic acid, acetic acid and ethanol. The final amounts of each product vary depending on the microorganism and conditions suitable for their growth and reproduction. Due to the formatehydrogen lyase complex, the mixed acid fermentation provides equimolar amounts of $\mathrm{CO}_{2}$ and $\mathrm{H}_{2}$. Pyruvate-formate lyase and lactate dehydrogenase enzyme complexes are sensitive to the presence of oxygen, which is why this fermentation requires an anaerobic environment. Some microorganisms can metabolize pyruvate via acetoin to butanediol (Ciani et al., 2013).

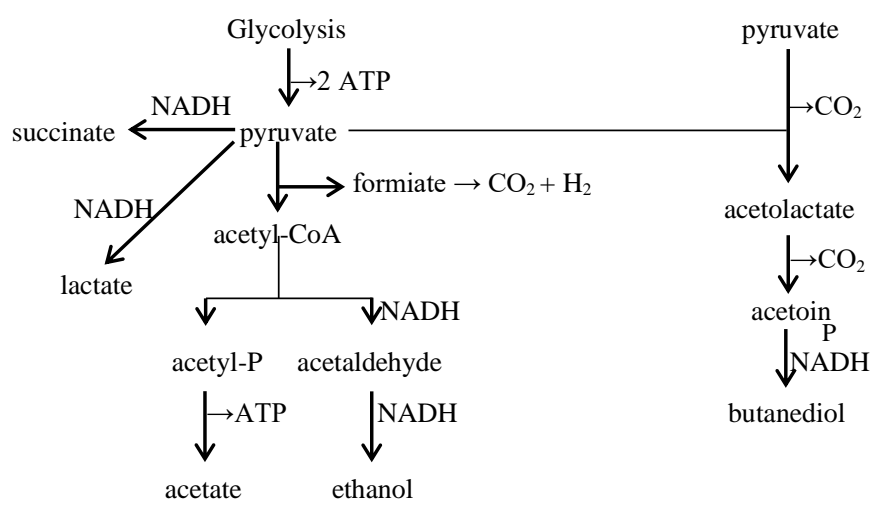

Figure 2 Mixed acid fermentation (Ciani et al., 2013)

It has been mentioned on several occasions that the metabolism of microorganisms present in the intestines takes advantage of FODMAP to produce short-chain fatty acids. By-products of this process include many gases, containing mainly hydrogen, methane, and hydrogen sulfide, which has a number of consequences on the health. Hydrogen is then used by the microorganisms in the gastrointestinal tract as a reducing agent (Nakamura et al., 2010). Hydrogenotrophic microorganisms are primarily methanogenic bacteria, followed by sulfate-reducing bacteria that convert sulfate to sulfide compounds as well as acetogens that produce acetate. Each of these species uses hydrogen to varying degrees and all are present in the human digestive tract (Doré, 1995; Nava et al., 2012; Wolf et al., 2016). Out of the methanogenic species, Methanobrevibacter smithii, Methanobrevibacter oralis, Methanosphaera stadtmanae, Methanomassiliicoccus luminyensis and Methanomassiliicoccus intestinalis have been detected in the human gut. Their presence has been linked to colon diseases (Chaudhary et al., 2018). Methanobrevibacter smithii is the most common or in some cases the only methanogen found in the human colon (Eckburg et al., 2005). Hydrogen and $\mathrm{CO}_{2}$ generated by the FODMAP fermentation are converted to methane as follows: $\mathrm{CO}_{2}$ $+4 \mathrm{H}_{2} \rightarrow \mathrm{CH}_{4}+2 \mathrm{H}_{2} \mathrm{O}$ (Moss et al., 2000). Sulfur-reducing bacteria, especially the genus Desulfovibrio, may be present in very small amounts in the large intestine (Nava et al., 2012). These present with the ability to reduce sulphates to hydrogen sulphide and at the same time convert lactate to acetate (Marquet $\boldsymbol{e t}$ al., 2009; Keller and Wall, 2011). Sources of sulphates are foods high in amino acids cysteine, methionine and taurine or inorganic sulphates, particularly plants of the Brassicaceae family (Magee $\boldsymbol{e t}$ al., 2000). Hydrogen and carbon dioxide produced by FODMAP fermentations may be used by some microorganisms in the large intestine for the so-called reductive acetogenesis: $4 \mathrm{H}_{2}+2 \mathrm{CO}_{2} \rightarrow \mathrm{CH}_{3} \mathrm{COO}^{-}+\mathrm{H}^{+}$ $+2 \mathrm{H}_{2} \mathrm{O}$ (Gibson et al., 1993). Such microorganisms include, for example, Ruminococcus hydrogenotrophicus (Bernalier et al., 1996) which uses the metabolic products of a number of mono- and disaccharides to generate acetate Acetate has a beneficial impact on the colon health since it lowers the $\mathrm{pH}$, transforming the environment into unsuitable for pathogens while being a source of energy for the microcenosis (Morrison and Preston, 2016).

\section{Fermentable disaccharides}

The most consumed FODMAP disaccharides are sucrose, containing glucose and fructose, the metabolism of which has been described above, followed by lactose ( $\beta$-D-galactopyranosyl- $(1 \rightarrow 4)$-D-glucose), which is normally hydrolyzed by the enzyme $\beta$-galactosidase in the small intestine to the monosaccharides glucose and galactose. Reduction or loss of $\beta$-galactosidase activity, e.g., with an increasing age or due to active gastrointestinal diseases, drugs or a pathologically rapid intestinal peristalsis leads to lactose malabsorption. Undigested lactose enters the large intestine, where it is fermented by the bacteria present in the large intestine into short-chain fatty acids and gases (hydrogen, methane, and carbon dioxide) Excessive gas production causes abdominal pain, cramps, bloating or vomiting, while a high osmotic loading of the colon causes diarrhea. Nevertheless, lactose intolerance occurs only in a relatively small number of people with lactose malabsorption. In other cases, bacterial fermentation of lactose as a carbohydrate belonging to FODMAP is associated with IBS. In the case of lactose, this condition is accompanied by a chronic diarrhea lasting longer than 4 weeks (Zheng $\boldsymbol{e t}$ al., 2015; Lacy and Patel, 2016; Xiong et al., 2017).

\section{Lactose fermentation}

Following hydrolysis of lactose to glucose and galactose, glucose is directly metabolized by glycolysis, while the major metabolic pathway for galactose utilization is the Leloir pathway (Fig. 3). Galactose is converted to glucose-1phosphate (glc-1P), which subsequently enters glycolysis, or to UDP-galactose (UDP-gal). In addition to converting UDP-glucose (UDP-glc) to UDP-galactose (UDP-gal), the enzyme UDP-galactose epimerase catalyzes the conversion of UDP-N-acetylgalactosamine (UDP-galNAc) and UDP-N-acetylglucosamine (UDP-glcNAc) (Leslie, 2003).

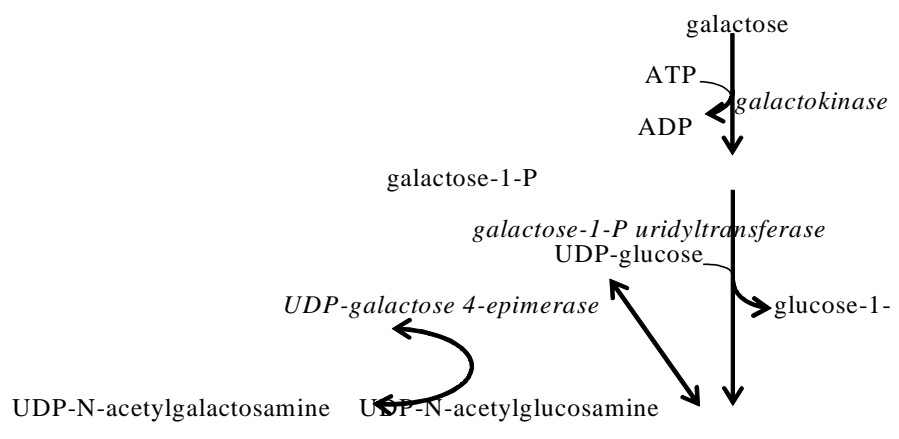

UDP-galactose

Figure 3 Leloir metabolic pathway (Qi and Tester, 2019)

Pyruvate as the glycolysis product, is fermented to lactate by probiotic bacteria (Pascual, 2008). Furthermore, microorganisms provide products of homofermentative (lactate) or heterofermentative (lactate, ethanol, acetic acid) lactic fermentation (Ciani et al., 2013).

\section{Fermentable oligosaccharides}

Oligosaccharides are generally poorly absorbed by the digestive tract, leading to them being fermented as undigested carbohydrates by the intestinal bacteria (Gibson and Shepherd, 2010; Barrett and Gibson, 2012; Barrett, 2013). This results in gas production and subsequent adverse events such as flatulence in both healthy and hypersensitive individuals (Ong et al., 2010).

Oligosaccharides are saccharides with a low degree of polymerization $(3-10$ monosaccharides, or in some cases up to 19 monosaccharides) and a low relative molecular weight, composed of monosaccharides. The structural properties of oligosaccharides determine the present monosaccharides and their bonds. For example, in fructooligosaccharides, D-fructose units are bound by $\beta-(2-1)$ bonds with a terminal D-glucose bound by an $\alpha-(1-2)$ bond. In xylooligosaccharides, $\beta$ xylose phosphates are bound by 1-4 bonds and contain arabinose or 4-methylglucuronic acid. Specific types of oligosaccharides, called indigestible oligosaccharides, resist hydrolysis and absorption in the upper gastrointestinal tract, but these can be fermented in the large intestine by intestinal bacteria Indigestible oligosaccharides have a prebiotic activity that can promote human health by increasing populations of beneficial microorganisms and/or their metabolic activity (Wang $\boldsymbol{e t}$ al., 2019). Naturally occurring oligosaccharide species and their sources are listed in Table 3 (Mussatto and Mancilha, 2007).

Table 3 Naturally occurring oligosaccharides (Wang et al., 2019) 


\begin{tabular}{lc}
\hline $\begin{array}{l}\text { Naturally occurring } \\
\text { oligosaccharides }\end{array}$ & Food source \\
\hline fructooligosaccharides & $\begin{array}{c}\text { artichokes, sugar cane, garlic, chicory, onion, } \\
\text { Jerusalem artichokes, wheat, honey }\end{array}$ \\
\hline xylooligosaccharides & bamboo shoots, fruits, vegetables, honey \\
\hline galactooligosaccharides & milk \\
\hline raffinose oligosaccharides & lentils, peas, beans, chickpeas, mallow, mustard \\
\hline cyclodextrins & water-soluble glycans \\
\hline
\end{tabular}

Prebiotic oligosaccharides are in particular fructooligosaccharides, galactooligosaccharides, xylooligosaccharides and soy oligosaccharides. Intestinal microorganisms metabolize these producing acetate, propionate, and butyrate by fermentation (Mussatto and Mancilha, 2007; Rivière et al., 2016). Their presence decreases the $\mathrm{pH}$ value in the large intestine, which can inhibit the growth of pathogenic bacteria as well as increase the resorption of minerals (Mussatto and Mancilha, 2007). In addition, they have mild anti-inflammatory effects an are involved in the regulation of lipogenesis (Flint et al., 2015) which contributes to their benefits for human health. Butyrate is the primary energy source for colonocytes, stimulates the growth of colonic epithelial cells and increases the absorption of salts and water, thereby alleviating constipation (Mussatto and Mancilha, 2007; Rivière et al., 2016). In addition, butyrate has also been found to be associated with the inhibition of colon and rectal cancer cell proliferation (Lim et al., 2005). Depending on the type of prebiotic oligosaccharides, the composition of these acids varies. For example, bifidobacteria produce acetate, lactate and formate but not butyrate (Sarbini and Rastall, 2011). Butyric acid is thus produced mainly by Faecalibacterium prausnitzii and Eubacterium rectale (Rivière et al., 2016).

Although indigestible oligosaccharides have health benefits, high consumption of these may cause flatulence, excessive gas production or diarrhea (Mussatto and Mancilha, 2007). Therefore, they are classified as FODMAP, which may worsen the symptoms of IBS (Rao et al., 2015).

In vivo studies from the last decade have shown that some indigestible oligosaccharides alter the composition of the intestinal microbiota at the species level (Scott $\boldsymbol{e t}$ al., 2013; Flint $\boldsymbol{e t}$ al., 2015). This is mainly because intestinal bacteria prefer different sources of carbon and energy in the environment, and present with different processes of oligosaccharide metabolism. The composition, structure of oligosaccharides and types of glycosidic bonds impact the selective use of these substances by intestinal bacteria at the strain level (Sarbini and Rastall, 2011; Hamaker and Tuncil, 2014)

Low molecular weight oligosaccharides are more rapidly fermented by Bifidobacterium sp. and Lactobacillum sp. This is because these oligosaccharides have more non-reducing ends, which are preferentially attacked, for example, by the bifidobacterial exoglucanase. However, the low molecular weight of oligosaccharides is also the reason for their complete decomposition before reaching the distal regions of the colon, which leads to an undesirable phenomenon typical for FODMAP (Sarbini and Rastall, 2011).

Nevertheless, in some cases, even large oligosaccharide molecules have been found to be fermented. Microorganisms may cooperate in their degradation (Scott et al., 2013; Rivière et al., 2016). For example, during in vitro co-culture experiments, Bifidobacterium longum (LMG 11047) was able to consume even fructose released from inulin, while Bacteroides thetaiotaomicron (LMG 11262) had a high digestive capacity for oligofructosan from inulin and therefore was identified as the dominant species in the environment (Sarbini and Rastall, 2011) In another case, fructose was released by Bifidobacterium longum (BB 536), which was then used by the bacterium Anaerostipes caccae (DSM 14662) (Sarbini and Rastall, 2011) in an oligofructosan environment. Such coexistence of bacteria has been defined as "the mechanism of cross-feeding" (Flint et al., 2015).

\section{Fructose-containing oligosaccharides}

There are three main types of fructans: inulins, levans (or fleins) and graminans Linear inulin consists of B-1,2-linked fructose residues attached to the sucrose core A typical source of such oligosaccharides are plants of the family Asterales, such as chicory. Inulins of the family Liliacae, which includes onions, contain two B1,2-linked fructose chains attached to a sucrose core. Levan-fructans, in turn, are found in grasses and consist of a fructose chain attached by a $\beta-2,6$ bond to sucrose. A mixture of fructans formed from B-2,6-linked fructose residues with B-1,2branches is called a graminan and is also found in grasses.

Fructans are widely used in the food industry. They are defined as soluble fiber and are available as a dietary supplement. Chicory inulin is an additive that emulsifies with water and is used as a fat substitute (Ritsema and Smeekens, 2003).

The most important FODMAP are inulin-type fructans, which have a linear chain with $\beta-2,1$ glycoside bonds, and which occur naturally in plant foods such as onions, garlic, leeks, asparagus, chicory root, artichokes and others (FrancoRobles and López, 2015). These fructans modulate the intestinal biocenosis by increasing the number of Bifidobacteria sp. and Lactobacilli sp. (OrtegaGonzález et al., 2013). Fructans selectively stimulate the activity and growth of beneficial microorganisms and at the same time inhibit the development of pathogenic microcenosis. The main products of fructan fermentation are shortchain fatty acids (especially acetate, propionate and butyrate) as well as gases including $\mathrm{H}_{2}, \mathrm{CO}_{2}$ and methane (Wong et al., 2006; Roberfroid, 2007; Roberfroid et al., 2010). These gases cause flatulence and convulsions, typical for the conditions caused by an increased consumption of FODMAP

\section{Galactose-containing oligosaccharides}

Following dietary fiber consumption, galactan is usually fermented in the large intestine, where it is broken down into galactooligosaccharides by the extracellular endo- $\beta-1,4$-galactanase encoded by the intestinal bacteria (Lammerts van Bueren et al., 2017). Galactooligosaccharides are prebiotic carbohydrates that are generally considered safe for consumption (Rastall, 2010; Lammerts van Bueren et al., 2017).

Plant galactans usually contain arabinose units (Zykwinska et al., 2008; Mohnen, 2008). According to the type of glycoside bond in the galactan backbone, arabinogalactans (AG) are divided into type AG-I with a 1,4-linked galactan backbone and type AG-II with a 1,3- and 1,6-linked backbone (Yapo, 2011). In plants, galactan is usually also associated with other structural molecules, such as ramnogalacturonan I. Hence, by different side chain substitutions, different chain lengths and overall structure, galactans form substances known as pectin (Mohnen, 2008).

In addition to prebiotic properties, galactans have gastroprotective effects (CantuJungles et al., 2014), arabinogalactans from Cereus triangularis possess antioxidant activities (Petera $\boldsymbol{e t}$ al., 2015), galactans isolated from Cereus peruvianus exhibit protective effects against the formation of gastric ulcers (Tanaka et al., 2010) and green tea arabinogalactans present with an insulinotropic effect (Wang et al., 2015).

\section{Oligosaccharides containing raffinose}

Raffinose oligosaccharides are a group of soluble sucrose derivatives found in the seeds, roots, tubers, and bulbs of several plants. They represent a storage form of carbohydrates for plants and are considered as substances with a protective effect against abiotic stress. The main representatives are trisaccharide raffinose (galactosylsucrose) and tetrasaccharide stachyose ( $\beta$-D-fructofuranosyl-O- $\alpha$-D galactopyranosyl- $(1 \rightarrow 6) \quad$-O- $\alpha$-D-galactopyranosyl- $(1 \rightarrow 6) \quad-\alpha$-D glucopyranoside)

Raffinose oligosaccharides are generally considered to be of low nutritional value due to their indigestibility. However, they have been found to have a beneficial effect on the intestinal microcenosis, and therefore their dietary intake is recommended in particular as a protection against intestinal oncological diseases (Chibbar and Båga, 2003). On the other hand, raffinose is a useful substrate for Escherichia coli, Enterococcus faecium, Streptococcus macedonicus, Streptococcus pasteurianus and Enterococcus avium, whose fermentation metabolism has been characterized by an intensive gas production (Mao et al., 2018).

\section{Oligosaccharides containing stachyose}

Stachyose, which consists of one glucose, one fructose and two galactose units, occurs naturally mainly in numerous vegetables, as well as in rice (Yin $\boldsymbol{e t}$ al., 2006). Although stachyose is not digestible for the human body due to $\alpha$ galactoside bonds (Baucells et al., 2000), its consumption is recommended as a prebiotic for several healthy intestinal bacteria (Li et al., 2013). Legumes are the most important food sources of stachyose. Fermentation of these indigestible oligosaccharides leads to the production of short chain gases and acids, which is why stachyose is classified among FODMAP.

\section{Fermentable polysaccharides}

Humans consume a wide range of dietary polysaccharides in the form of plant foods, animal connective tissue, food additives, and higher mushroom products (Martens et al., 2014). However, the human body can only cleave $\alpha-1,4$-linked polymers of glucose (including starches, maltodextrins, maltotriose and maltose), lactose and sucrose (Kaoutari et al., 2013) which is why the intestinal microcenosis has an irreplaceable role in the polysaccharide metabolism. Microorganisms produce a wide range of glycolytic enzymes (Gill $\boldsymbol{e t}$ al., 2006; Turnbaugh et al., 2009; Turnbaugh et al., 2010), capable of cleaving bonds in $\beta$-glucans, cellulose, or hemicelluloses. In addition to the positive prebiotic effect, polysaccharides are fermented by microbial metabolism to produce short-chain fatty acids and gases. For example, Plantago asiatica polysaccharides are fermented by the microcenosis to acetic, propionic, and butyric acids. These are the products of acetic, propionic and butane fermentation, which, however, also release large amounts of carbon dioxide and hydrogen (Hu et al., 2013). A frequently used food additive is guar gum (from the seeds of Cyamopsis tetragonoloba). It is used as a thickener, increases the feeling of satiety, and reduces the absorption of monosaccharides. It is an indigestible fiber and is fermented by intestinal microorganisms accompanied by an intensive production of propionate, butyrate, and gases (Yang et al., 2013). 


\section{Carbohydrate polyols}

Carbohydrate polyols are alcohols formed by the reduction of carbohydrates. In the food industry, they are used as thickeners and sweeteners, which have a low glycemic index. They are either obtained by an extraction from raw plant materials or by a reduction of monosaccharides, particularly glucose and fructose. These are used as a sugar substitute in low-calorie drinks, confectionery, pastries, yoghurts, or separately as low-calorie sweeteners. The most important representatives are sorbitol and mannitol.

Both sorbitol (D-glucitol) and mannitol (an isomer of sorbitol) occur naturally in fruits such as apples, cherries, and apricots; commercially available polyols for food purposes are prepared by hydrogenation of monosaccharides. Sorbitol has a relative sweetness of about $55 \%$ and mannitol about $50 \%$ when compared to sucrose (Featherstone, 2015). In soft drinks, a 1-2\% sorbitol solution is usually used to ensure a cool and sweet mouthfeel, as well as to enhance the taste. Sorbito is also used to mask a typical bitter taste of saccharin in beverages containing this sweetener. One of the main differences between sorbitol and mannitol lies in their solubility. Sorbitol is highly soluble in water and is an excellent hygroscopic agent. Mannitol is significantly less soluble and is used as a carrier for flavorings in e.g., powdered beverage bases (Featherstone, 2015).

\section{Fermentation of mannitol and sorbitol}

Enterobacter aerogenes ferments mannitol via glucose and pyruvate with a simultaneous intensive $\mathrm{H}_{2}$ production (Tanisho and Suganuma, 1999). Mannitolbased fermentation is twice as intense as fermentation, in which glucose is the starting substrate when it comes to the production of hydrogen (Tanisho and Ishiwana, 1994; Hongo, 2014) (Fig. 4).

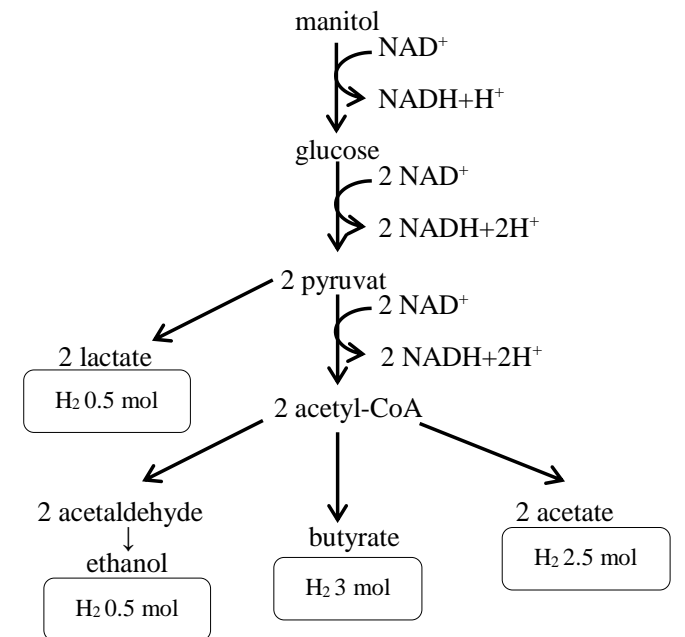

Figure 4 Mannitol fermentation (Hongo, 2014)

Due to a long tradition of using these sweeteners and research on them, it was found as early as 1986 that sorbitol altered the fecal microcenosis in rats by displacing gram-negative bacteria and promoting the growth of gram-positive bacteria (Salminen et al., 1986). For example, sorbitol promotes the growth and reproduction of Lactobacillus reuteri in the digestive tract of rats and is metabolized with a marked increase in butyrate concentration in the colon (Sarmiento-Rubiano et al., 2007). However, butane fermentation also produces gases, which is why flatulence and colicky pain are an undesirable side effect of polyol consumption. Therefore, both sorbitol and mannitol have been classified as FODMAP.

\section{FODMAP food sources}

To alleviate IBS and the inconveniences associated with bacterial overgrowth in the intestine, in which gaseous substances are produced by fermentation, it is necessary to describe the FODMAP food sources (Tab. 4) as well as foods that can be consumed since they contain little or no FODMAP.

Table 4 Foods high in FODMAP (Gibson and Shepherd, 2005, 2010, 2012)

\begin{tabular}{|c|c|c|}
\hline FODMAP & Subcategory & Food \\
\hline \multirow{2}{*}{ fructooligosaccharides } & \multirow{2}{*}{ fructans } & $\begin{array}{c}\text { Cereals: wheat, rye, barley } \\
\text { Vegetables: onion, garlic, artichoke, leek, beet and cabbage }\end{array}$ \\
\hline & & $\begin{array}{c}\text { Fruit: melon, peaches, hurmikaki, plums, nectarines and most dried } \\
\text { fruit }\end{array}$ \\
\hline \multirow{2}{*}{ galactooligosaccharides } & \multirow{2}{*}{ galactans } & $\begin{array}{c}\text { Legumes: beans, soybeans, peas, chickpeas } \\
\end{array}$ \\
\hline & & Vegetables: beet \\
\hline disaccharides & lactose & Dairy products from cow's and goat's milk \\
\hline \multirow[t]{2}{*}{ monosaccharides } & \multirow[t]{2}{*}{ fructose in excess of glucose } & $\begin{array}{c}\text { Fruits: apples, pears, melon, mango, cherries, blackberries, fruit } \\
\text { juices, honey } \\
\text { Sweeteners: high-fructose corn syrup }\end{array}$ \\
\hline & & $\begin{array}{l}\text { Vegetables: asparagus, sugar peas } \\
\end{array}$ \\
\hline \multirow{2}{*}{ carbohydrate alcohols } & \multirow{2}{*}{ polyols } & $\begin{array}{c}\text { Fruits: apples, pears, avocados, apricots, blueberries, nectarines, } \\
\text { peaches, plums, prunes, and melon }\end{array}$ \\
\hline & & $\begin{array}{c}\text { Vegetables: sweet potatoes, mushrooms, cauliflower and sugar } \\
\text { peas }\end{array}$ \\
\hline
\end{tabular}

The importance of diet in the treatment of IBS was confirmed by a study in which $76 \%$ of patients diagnosed with IBS and fructose malabsorption experienced a significant remission of digestive issues following a well-defined diet without fructose and fructooligosaccharides (Shepherd and Gibsond, 2006; Shepherd $\boldsymbol{e t}$ al., 2008). A LOW-FODMAP diet significantly improved health in $75 \%$ of patients diagnosed with IBS (Marsh et al., 2015), and consequently, 60-70\% of patients reported a worsening of symptoms after switching to normal eating habits (Ahmad and Akbar, 2015; El-Salhy and Gundersen, 2015; Lacy and Patel, 2015). However, there are also hypersensitive individuals who have not been diagnosed with any gastrointestinal diseases or syndromes and still have major problems after consuming HIGH-FODMAP foods. In these subjects, the consumption of foods rich in FODMAP followed by physical exertion, the movement of food through the upper gastrointestinal tract was intensified and carbohydrates were then fermented in the large intestine (Peters, 2006; de Oliveira and Burini, 2009; Peters et al., 2014).

The sources of fructose are mainly fruits (apples, cherries, mangoes, pears, watermelon), vegetables (asparagus, artichokes, sugar peas), honey and HFCS syrup with a high fructose content (Tab. 5) (Latulippe and Skoog, 2011; Douard and Ferraris, 2012).
Table 5 Fructose content in fruits and vegetables (Nookaraju et al., 2010)

\begin{tabular}{lccc}
\hline Fruits & $\begin{array}{c}\text { Fructose, } \\
\text { g per 100 }\end{array}$ & Vegetables & $\begin{array}{c}\text { Fructose, } \\
\text { g per 100 g }\end{array}$ \\
\hline Apples & 5.9 & Tomatoes & 1.4 \\
\hline Pears & 6.5 & Green peppers & 1.0 \\
\hline Cherries & 5.4 & Red peppers & 2.4 \\
\hline Plums & 2.8 & Cucumbers & 0.7 \\
\hline Apricots & 0.6 & Broccoli & 1.3 \\
\hline Peaches & 1.2 & Onion & 1.8 \\
\hline Strawberries & 2.4 & Cauliflower & 1.3 \\
\hline Raspberries & 1.2 & Carrot & 1.9 \\
\hline Blackberries & 2.5 & Red cabbage & 1.7 \\
\hline Black currants & 5.0 & Cabbage & 2.0 \\
\hline Red currants & 1.8 & Brussels sprouts & 0.8 \\
\hline Grapefruits & 1.0 & Watermelon & 3.5 \\
\hline Grapes & 7.1 & Potatoes & 0.1 \\
\hline Pineapple & 1.4 & Sweet potatoes & 0.8 \\
\hline Bananas & 3.8 & Kidney bean \\
\hline & \multicolumn{3}{c}{0.7} \\
\hline
\end{tabular}


Lactose is considered a FODMAP when there is an insufficient amount of $\beta$ galactosidase in the digestive tract (estimated to be lacking in about $15 \%$ of the population), an enzyme required for its hydrolysis (Carter and Attel, 2013). Milk and milk products, ice cream, puddings and soft, unfermented cheeses are among the most prominent sources of lactose (Tab. 6).

Table 6 Lactose content in dairy products (Agostoni et al., 2010)

\begin{tabular}{lc} 
Food & $\begin{array}{c}\text { Lactose, } \\
\text { g per 100 g }\end{array}$ \\
\hline Cow milk & 4.8 \\
\hline Goat milk & 4.4 \\
\hline Sheep's milk & 5.1 \\
\hline Human milk & 7.2 \\
\hline Yoghurt & 4.1 \\
\hline Kefir & 3.8 \\
\hline Cream & 3.1 \\
\hline Ice cream & 6.0 \\
\hline Swiss cheese & 0.0 \\
\hline Cottage cheese & 2.2 \\
\hline Butter & 0.7 \\
\hline Milk powder, full fat & 38.0 \\
\hline Milk powder, without fat & 52.0 \\
\hline Whey dried & 74.0
\end{tabular}

FODMAP oligosaccharides are fructans and galactans whose digestion an absorption are not possible in the human body since the digestive juices do not contain the necessary enzymes (Roberfroid and Delzenne, 1998; Ritsema and Smeekens, 2003; Sangwan et al., 2011). Fructooligosaccharides are found in various fruits, cereals and legumes, nuts, and vegetables. Peaches, hurmikaki, melons, artichokes, beetroot, brussels sprouts, chicory, fennel, garlic, leeks, onions, peas, wheat, rye, barley, oats, pistachios, lentils, chickpeas, and chicory drinks contain high amounts of fructans (Roberfroid and Delzenne, 1998; Ritsema and Smeekens, 2003). Wheat, containing $1-4 \%$ of these oligosaccharides, is also an important food source of fructans (Roberfroid and Delzenne, 1998). Therefore, wheat products such as bread, pasta, breakfast cereals, bakery and pastry goods are considered as foods containing FODMAP. Rye also contains fructans, which, however, have a longer chain length than wheat fructans and therefore present with a lower osmotic activity and are more slowly fermented, allowing them to pass through the digestive tract as undigested (Roberfroid and Delzenne, 1998; Ritsema and Smeekens, 2003; Sangwan et al., 2011; Van Loo et al., 1995; Karppinen et al., 2003). Inulin crops are a frequently consumed source of fructans. Inulin, as a long-chain fructan with a degree of polymerization greater than 10, has a prebiotic effect (Roberfroid, 1999; Boeckner et al., 2001, Kaur and Gupta, 2002; Kelly, 2008). Its food sources are chicory root, leeks, onions, garlic, artichokes, fennel, and asparagus (Tab. 7)

Table 7 Inulin content in inulin crops (Fuchs, 2012)

\begin{tabular}{lcc}
\hline Source & Storage organ & $\begin{array}{c}\text { Inulin content, \% of fresh } \\
\text { weight }\end{array}$ \\
\hline Asparagus & root & $10-15$ \\
\hline Chicory & root & $15-20$ \\
\hline Dandelion & root, leaves & $12-15$ \\
\hline Garlic & bulb & $9-16$ \\
\hline Jerusalen artichoke & tuber & $14-19$ \\
\hline
\end{tabular}

Table 8 Galactooligosaccharides in food (Steggerda et al., 1966)

\begin{tabular}{lc}
\hline Food & Galactan, g per 100 $\mathbf{g}$ whole product \\
\hline Jerusalem artichoke & 7.5 \\
\hline Beans, baked & 0.6 \\
\hline Beans, black-eyed & 0.3 \\
\hline Beans, broad & 0.2 \\
\hline Beans, butter & 0.2 \\
\hline Beans, kidney & 0.2 \\
\hline Bean, lima (dried) & 2.9 \\
\hline Beans, red & 0.8 \\
\hline Beetroot & 0.1 \\
\hline Broccoli & 0.1 \\
\hline Chickpeas & 1.2 \\
\hline Fennel, bulb & 0.1 \\
\hline Lentils, dried & 3.8 \\
\hline Lettuce, radicchio & 0.1 \\
\hline Onion, white & 0.2 \\
\hline Peas, green (frozen) & 0.2 \\
\hline Soy beverages & $0.3-0.9$ \\
\hline
\end{tabular}

The primary food sources of galactans encompass legumes and their products, such as beans, chickpeas, lentils and soy products (Table 8), as well as cruciferous vegetables such as cabbage or kale (Steggerda et al., 1966). Vegetarians have the highest intake of galactans, for whom legumes are a source of protein, alongside nations for which e.g. beans represent a traditional or national dish ("chili con carne" typical for Mexicans) (Roberfroid and Delzenne, 1998).

The polyols sorbitol and mannitol, as well as maltitol, xylitol, erythritol or polydextrose, are storage substances in plants and play an osmoregulatory role Sorbitol is more common in fruits, while mannitol is more frequent in vegetables. Foods with a higher sorbitol content include apples, apricots, avocados, blackberries, cherries, nectarines, pears, plums, diet drinks, confectionery and chewing gums. Mannitol is found mainly in mushrooms, cauliflower, celery, and peas. Polyols are also used as artificial sweeteners such as E420 (sorbitol), E421 (mannitol), E965 (maltitol), E967 (xylitol) and E953 (isomalt) (Hyams, 1983; Beaugerie et al., 1990; Barrett and Gibson, 2012).

\section{Low FODMAP diet}

The primary solution to the problems associated with the consumption of FODMAP lies in a strict elimination diet. A reduction of a high FODMAP food consumption in up to $70 \%$ of patients with irritable bowel syndrome has led to a significant health improvement (Gearry et al., 2016; Marsh et al., 2015; Gibson, 2017). Patients on a low FODMAP diet have presented with a significantly reduced abdominal pain and bloating (Altobelli, 2017). With respect to the irritable bowel syndrome, patients on a low FODMAP diet had lower serum levels of the proinflammatory interleukins IL-6 and IL-8, decreased concentrations of short-chain fatty acids and a reduced presence of Actinobacteria, Bifidobacterium, Faecalibacterium prausnitzii in their stool (Staudacher et al., 2012; Staudacher et al., 2014; Staudacher and Whelan, 2016). In addition to a low FODMAP diet, patients with irritable bowel syndrome are also advised to reduce their intake of fiber and foods that may cause bloating, as well as to reduce the consumption of alcohol, caffeine, and fatty foods. (Non)consumption of milk and dairy products is debatable, as not all patients present with a lactose intolerance (Altobelli $\boldsymbol{e t}$ al., 2017; Tuck et al., 2014).

However, a low FODMAP diet may also come along with several negative side effects. Fructans and galactans are carbohydrates with a prebiotic effect. They act as substrates for the growth of a healthy microcenosis in the intestines and are a part of the so-called soluble fiber. Their presence enforces a proper function of the intestines. As such, elimination of FODMAP from nutrition may result in a disproportionately low fiber intake, a reduction of prebiotic substances, and thus undesirable changes in the composition of the intestinal microbiota towards a reduction of the beneficial bacteria (Hill et al., 2017). Stool analysis has revealed that a very low FODMAP diet lasting for 3-4 weeks led to a reduction in Bifidobacteria (Kerckhoffs et al., 2009; Halmos et al., 2014). The number of butyrate-producing bacteria also decreased, while on the other hand the number of mucus degrading bacteria increased. This finding leads to the conclusion that if irritable bowel syndrome is associated with a dysbiosis, then a long-term low FODMAP diet is not an appropriate solution. As such, the diet is recommended for 2 - 6 weeks, or until pathological symptoms disappear. Subsequently, a professional dietary management with at least a partial return of FODMAP to food is required.

\section{CONCLUSION}

Fermentable disaccharides, oligosaccharides, polysaccharides and polyols are commonly found in a wide range of foods and play an important role in nutrition. They are a part of fiber, which contributes to a healthy function of the entire gastrointestinal tract. On the other hand, their ingestion may cause a variety of unpleasant difficulties to sensitive individuals. The possible solution lies in a low FODMAP diet, which, however, does not only come with benefits. Adverse side effects may occur after a long-term avoidance of these carbohydrates from food. Further studies are needed to assure a healthy functioning of the digestive tract.

Acknowledgments: This publication was supported by the Operational program Integrated Infrastructure within the project: Demand-driven research for the sustainable and inovative food, Drive4SIFood 313011V336, cofinanced by the Euruopean Regional Development Fund.

\section{REFERENCES}

Agostoni, C., Bresson, J., Fairweather-Tait, S., Flynn, A., Golly, I., Korhonen, H., Lagiou, P., Løvik, M., Marchelli, R., Martin, A., Moseley, B., Neuhäuser-Berthold, M., Przyrembel, H., Salminen, S. Sanz, Y., Strain, J., Strobel, S., Tetens, I., Tomé, D., Loveren, H., Verhagen, H. (2010). Scientific Opinion on lactose thresholds in lactose intolerance and galactosaemia. EFSA Panel on Dietetic Products, Nutrition and Allergies (NDA), 8(9), 1-29. https://doi.org/10.2903/j.efsa.2010.1777

Ahmad, O. F., Akbar, A. (2015). Dietary Threatment of Irritable Bowel Syndrome. British Medical Bulletin, 113(1), 83-90. https://doi.org/10.1093/bmb/1du039 Altobelli, E., Del Negro, V., Angeletti, P., Latella, G. (2017). Low-FODMAP Diet Improves Irritable Bowel Syndrome Symptoms: A Meta-Analysis. Nutrients, 9(9), 940. https://doi.org/10.3390/nu9090940

Astwood, K., Lee, B., Manley-Harris, M. (1998). Oligosaccharides in New Zealand Honeydew Honey.Journal of Agricultural and Food Chemistry, 46(12), 4958-4962. https://doi.org/10.1021/jf980720d 
Barrett, J. S. (2013). Extending Our Knowledge of Fermentable, Short-Chain Carbohydrates for Managing Gastrointestinal Symptoms. Nutrition in Clinical Practice, 28(3), 300-306. https://doi.org/10.1177/0884533613485790

Barrett, J. S., Gibson, P. R. (2012). Fermentable oligosaccharides, disaccharides, monosaccharides and polyols (FODMAPs) and nonallergic food intolerance: FODMAPs or food chemicals? Therapeutic Advances in Gastroenterology, 5(4), 261-268. https://doi.org/10.1177/1756283X11436241

Baucells, M. D., Crespo, N., Barroeta, A. C., Lopez-Ferrer, S., Grashorn, M. A (2000). Incorporation of different polyunsaturated fatty acids into eggs. Poultry Science, 79(1), 51-59. https://doi.org/10.1093/ps/79.1.51

Beaugerie, L., Flourié, B., Marteau, P., Pellier, P., Franchisseur, C., Rambaud, J.C. (1990). Digestion and absorption in the human intestine of three sugar alcohols Gastroenterology, 99(3), 717-723. https://doi.org/10.1016/0016-5085(90)90960-

Bernalier, A., Willems, A., Leclerc, M. (1996). Ruminococcus hydrogenotrophicus sp. nov., a new $\mathrm{H} 2 / \mathrm{CO} 2$-utilizing acetogenic bacterium isolated from human feces. Arch Microbiol 166, 176-183. https://doi.org/10.1007/s002030050373

Bhagavan, N. V., Ha, Ch. (2011). Carbohydrate metabolism II: Gluconeogenesis, Glycogen Synthesis and Breakdown, and Alternative Pathways. Essentials of Medical Biochemistry with clinical cases, 151-168. https://doi.org/10.1016/B9780-12-095461-2.00014-X

Boeckner, L. S., Schnepf, M. I., Tungland, B. C. (2001). Inulin: A review of nutritional and health implications. Advances in Food and Nutrition Research, 163. https://doi.org/10.1016/S1043-4526(01)43002-6

Bogdanov, S., Haldimann, M., Luginbühl, W., Gallmann, P. (2007). Minerals in honey: enviromental, geographical and botanical aspects. Journal of Apicultural Research, 46(4), 269-275. https://doi.org/10.1080/00218839.2007.11101407

Borrel, G., Lehours, A., Crouzet, O., Jezequel, D., Kulozak, A., Duffaud, E., Joblin, K., Fonty, G. (2012). Stratification of Archaea in the Deep Sediments of a Freshwater Meromictic Lake: Vertical Shift from Methanogenic to Uncultured Archaeal Lineages. PLoS ONE, 7(8), e43346. https://doi.org/10.1371/journal.pone.0043346

Bouhnik, Y. Alain, S., Attar, A., Flourié, B., Raskine, L., LePors, M. J. S. Rambaud, J. (1999). Bacterial populations contaminating the upper gut in patients with small intestinal bacterial overgrowth syndrome. The American Journal of Gastroenterology, 94(5), 1327-1331. https://doi.org/10.1016/S00029270(99)00071-4

Cani, P., Delzenne, N. M. (2007). Gut microflora as a target for energy and metabolic homeostasis. Clinical Nutrition and Metabolic Care, 10(6), 729-734. https://doi.org/10.1097/MCO.0b013e3282efdebb

Cantu-Jungles, T. M., Maria-Ferreira, D., da Silva, L. M., Baggio, C. H., Werner, M. F. de P., Iacomini, M., Cordeiro, L. M. C. (2014). Polysaccharides from prunes Gastroprotective activity and structural elucidation of bioactive pectins. Food Chemistry, 146, 492-499. https://doi.org/10.1016/j.foodchem.2013.09.09

Carter, S. L., Attel, S. (2013). The diagnosis and management of patients with lactose-intolerance. The Nurse Practitioner, 38(7), 2328. https://doi.org/10.1097/01.npr.0000429894.03255.80

Ciani, M., Comitini, F., Mannazzu, I. (2013). Fermentation. Earth systems and Enviromental Sciences, 2, 310-321. https://doi.org/10.1016/B978-0-12-4095489.00693-X

De Oliveira, E. P., Burini, R. C. (2009). The impact of physical exercise on the gastrointestinal tract. Current Opinion in Clinical Nutrition and Metabolic Care, 12(5), 533-538. https://doi.org/10.1097/mco.0b013e32832e6776

Doner, L. W. (1977). The sugars of honey - A review. Journal of the science of food and agriculture, 28(5), 443-456. https://doi.org/10.1002/jsfa.2740280508

Doré, A. (1995). Barents Sea Geology, Petroleum Resources and Commercial Potential. Arctic, 48(3), 207-221. https://doi.org/10.14430/arctic1243

Douard, V., Ferraris, R. R. (2012). The role of fructose transporters in diseases linked to excessive fructose intake. The Journal of Physiology, 591(2), 401-414. https://doi.org/10.1113/jphysiol.2011.215731

Eberhard, J., Jepsen, S., Pohl, L., Albers, H. K., Acil, Y. (2002). Bacteria Challenge Stimulates Formation of Arachidonic Acid Metabolites by Human Keratinocytes and Neutrophils In Vitro. Clinical and Vaccine Immunology, 9(1), 132-137. https://doi.org/10.1128/CDLI.9.1.132-137.2002

Eckburg, P. B., Bik, E. M., Purdom, E., Dethlefsen, L., Sargent, M., Gill, S. R. Nelson, K. E., Relman, D. A. (2005). Diversity Of The Human Intestinal Microbia Flora. Science, 308(5728), 1635-1638. https://doi.org/10.1126/science.1110591

El-Salhy, M., Gundersen, D. (2015). Diet in irritable bowel syndrome. Nutrition Journal, 14(13). https://doi.org/10.1186/s12937-015-0022-3

Featherstone, S. (2015). Ingredients used in the preparation of canned foods A Complete Course in Canning and Related Processes, 2, 147-211. https://doi.org/10.1016/B978-0-85709-678-4.00008-7

Fedewa, A., Rao, S. S. C. (2014). Dietary Fructose Intolerance, Fructan Intolerance and FODMAPs. Current Gastroenterology Reports, 16(1). https://doi.org/10.1007/s11894-013-0370-0

Flemer, B., Warren, R. D., Barret, M., Cisek, K., Das, A., Jeffery, I. B., Hurley, E., Shanahan, F., O'Toole, P. W., O'Riordain, M. (2018). The oral microbiota in colorectal cancer is distinctive and predictive. Gut, 67(8), 1454-1463. https://doi.org/10.1136/gutjnl-2017-314814
Flint, H., Duncan, S., Scott, K., Louis, P. (2015). Links between diet, gut microbiota composition and gut metabolism. Proceedings of the Nutrition Society, 74(1), 13-22. https://doi.org/10.1017/S0029665114001463

Flint, H., Scott, K., Louis, P., Duncan, S. H. (2012). The role of the gut microbiota in nutrition and health. Nature Reviews Gastroenterology \& Hepatology, 9(10), 577-589. https://doi.org/10.1038/nrgastro.2012.156

Franco-Robles, E., López, M. G. (2015). Implication of Fructans in Health Immunomodulatory and Antioxidant Mechanisms. The Scientific World Journal, 1-15. https://doi.org/10.1155/2015/289267

Fuchs, A. (1993). Inulin and inulin-containing crops. Studies in Plant Science. https://doi.org/10.1016/c2009-0-01053-8

Gearry, R., Skidmore, P., O'Brien, L., Wilkinson, T., Nanayakkara, W. (2016). Efficacy of the low FODMAP diet for treating irritable bowel syndrome: the evidence to date. Clinical and Experimental Gastroenterology, 131 https://doi.org/10.2147/ceg.s86798

Gaci, N., Borrel, G., Tottey, W., O'Toole, P. W., Brugère, J. F. (2014). Archaea and the human gut: new beginning of an old story. World journal of gastroenterology, 20(43),

https://doi.org/10.3748/wjg.v20.i43.16062

Geidl-Flueck, B., Hochuli, M., Némenth, Á., Eberi, A., Derron, N., Köfeler, H. C., Tappy, L., Berneis, K., Spinas, G. A., Gerber, P. A. (2021). Fructose- and sucrosebut not glucose-sweetened beverages promote hepatic de novo lipogenesis: A randomized controlled trial. Journal of Hepatology, 75(1), 46-54 https://doi.org/10.1016/j.jhep.2021.02.027

Ghoshal, U. C., Shukla, R., Ghoshal, U., Gwee, K., Ng, S. C., Quigley, E. M. M. (2012). The Gut Microbionta and Irritable Bowel Syndrome: Friend or Foe International Journal of Inflammation, 2012, 1-13. https://doi.org/10.1155/2012/151085

Ghoshal, U. C., Srivastava, D. (2014). Irritable bowel syndrome and small intestinal bacterial overgrowth: meaningful association or unnecessary hype. World journal of gastroenterology,20(10), 2482-2491. https://doi.org/10.3748/wjg.v20.i10.2482

Gibson, G. R., Macfarlane, G. T., Cummings, J. H. (1993). Sulphate reducing bacteria and hydrogen metabolism in the human large intestine. Gut, 34(4), 437439. https://doi.org/10.1136/gut.34.4.437

Gibson, G. R., Roberfroid, M. B. (1995). Dietary Modulation of the Human Colonic Microbiota: Introducing the Concept of Prebiotics. The Journal of Nutrition, 125(6), 1401 - 1412. https://doi.org/10.1093/jn/125.6.1401

Gibson, P. R. (2017). The evidence base for efficacy of the low FODMAP diet in irritable bowel syndrome: is it ready for prime time as a first-line therapy? Journal of Gastroenterology and Hepatology, 32, 32-35. https://doi.org/10.1111/jgh.13693

Gibson, P. R., Shepherd, S. J. (2005). Personal view: food for thought - western lifestyle and susceptibility to Crohn's disease. The FODMAP hypothesis Alimentary Pharmacology and Therapeutics, 21(12), 1399-1409. https://doi.org/10.1111/j.1365-2036.2005.02506.x

Gibson, P. R., Shepherd, S. J. (2010). Evidence-based dietary management of functional gastrointestinal symptoms: The FODMAP approach. Journal of Gastroenterology and Hepatology, 25(2), 252258. https://doi.org/10.1111/j.1440-1746.2009.06149.x

Gibson, P. R., Shepherd, S. J. (2012). Food Choice as a Key Management Strategy for Functional Gastrointestinal Symptoms. The American Journal of Gastroenterology, 107(5), 657-666. https://doi.org/10.1038/ajg.2012.49

Gill, S. R., Pop, M., DeBoy, R. T., Eckburg, P. B., Turnbaugh, P. J., Samuel, B. S., Nelson, K. E. (2006). Metagenomic Analysis of the Human Distal Gut $\begin{array}{lll}\text { Microbiome. } & \text { Science, } & 312(5778),\end{array}$ 1359. https://doi.org/10.1126/science.1124234

Giorgio, R., Volta, U., Gibson, P. R. (2016). Sensitivity to wheat, gluten and FODMAPs in IBS: facts or fiction? Gut, 65(1), 169-178 https://doi.org/10.1136/gutjnl-2015-309757

Gomara, R. E., Halata, M. S., Newman, L. J., Bostwick, H. E., Berezin, S. H. Cukaj, L., See, M. C., Medow, M. S. (2008). Fructose Intolerance in Children Presenting With Abdominal Pain. Journal of Pediatric Gastroenterology and Nutrition, 47(3), 303-308. https://doi.org/10.1097/MPG.0b013e318166cbe4

Guarner, F., Malagelada, J. (2003). Gut flora in health and disease. The Lancet, 361(9356), 512-519._https://doi.org/10.1016/S0140-6736(03)12489-0

Halmos, E. P., Christophersen, C. T., Bird, A. R., Shepherd, S. J., Gibson, P. R., Muir, J. G. (2014). Diets that differ in their FODMAP content alter the colonic luminal microenvironment. Gut, 64(1), 93-100. https://doi.org/10.1136/gutjnl2014-307264

Hamaker, B. R., Tuncil, Y. E. (2014). A Perspective on the Complexity of Dietary Fiber Structures and Their Potential Effect on the Gut Microbiota. Journal of Molecular Biology, 426(23), 3838-3850.

https://doi.org/10.1016/j.jmb.2014.07.028

Hedayat, K. M., Lapraz, J. (2019). Disorders of intestinal transit. The Theory of Endobiogeny, 3, 215-235. https://doi.org/10.1016/B978-0-12-816964-3.00010-9 Hill, P., Muir, J. G., Gibson, P. R. (2017). Controversies and Recent Developments of the Low-FODMAP Diet. Gastroenterology \& hepatology, 13(1), 36-45. https://www.ncbi.nlm.nih.gov/pmc/articles/PMC5390324/ 
Hongo, A. (2014). Optimization of Hydrogen Production by Mannitol Utilizing a Bacterium Strain TM1. Journal of Enveronmental Biotechnology, 14(1), 65-68. https://www.jseb.jp/wordpress/wp-content/uploads/14-01-065.pdf

Hu, J.-L., Nie, S.-P., Li, C., Xie, M.-Y. (2013). In vitro fermentation of polysaccharide from the seeds of Plantago asiatica L. by human fecal microbiota. Food Hydrocolloids, $33(2)$,

384 392. https://doi.org/10.1016/j.foodhyd.2013.04.006

Hyams, J. S. (1983). Sorbitol Intolerance: An Unappreciated Cause of Functional Gastrointestinal Complaints. Gastroenterology, 84(1), 30-33. https://doi.org/10.1016/S0016-5085(83)80163-2

Chaudhary, P.P., Conway, P.L., Schlundt, J. (2018). Methanogens in humans: potentially beneficial or harmful for health. Applied Microbiology and Biotechnology, 102, 3095-3104. https://doi.org/10.1007/s00253-018-8871-2

Chibbar, R. N., Båga, M. (2003). Genetic Modification Of Primary Metabolism Carbohydrates. Encyclopedia of Applied Plant Sciences, 449-459. https://doi.org/10.1016/B0-12-227050-9/00171-X

Chumpitazi, B. P., Shulman, R. J. (2016). Dietary Carbohydrates and Childhood Functional Abdominal Pain. Annals of Nutrition and Metabolism, 68(1), 7-18 https://doi.org/10.1159/000445390

Iannitti, T., Palmieri, B. (2010). Therapeutical use of probiotic formulations in clinical practice. Clinical Nutrition, 29(6), 701-725. https://doi.org/10.1016/j.clnu.2010.05.004

Kåhrström, C., Pariente, N., Weiss, U. (2016). Intestinal microbionta in health and disease. Nature, 535(7610), 47-47. https://doi.org/10.1038/535047a

Kaoutari, A. E., Armougom, F., Gordon, J. I., Raoult, D., Henrissat, B. (2013). The abundance and variety of carbohydrate-active enzymes in the human gut microbiota. Nature Reviews Microbiology, 11(7), 497 504. https://doi.org/10.1038/nrmicro3050

Karppinen, S., Myllymäki, O., Forssell, P., Poutanen, K. (2003). Fructan Content of Rye and Rye Products. Cereal Chemistry Journal, 80(2), 168-171. https://doi.org/10.1094/CCHEM.2003.80.2.168

Kaškoniene, V., Venskutonis, P. R. (2010). Floral markers

in honey of various botanical and geographic origins:

Comprehensive Reviews. Food Science and Food Safety,

9, 620-634. https://doi. org/10.1111/j

Kaur, N., Gupta, A. K. (2002). Applications of inulin and oligofructose in health and nutrition. Journal of Biosciences, 27(7), 703714. https://doi.org/10.1007/bf02708379

Keller, K. L., Wall, J. D. (2011). Genetics and molecular biology of the electron flow for sulfate respiration in Desulfovibrio. Frontiers in Microbiology. https://doi.org/10.3389/fmicb.2011.00135

Kelly, G. (2008). Inulin Type Prebiotics --A Review: Part 1. Alternative Medicine Review, 13(4), 315-329.

https://web.p.ebscohost.com/abstract?site=ehost\&scope=site \&jrnl=10895159\&A $\mathrm{N}=36459239 \& \mathrm{~h}=\mathrm{rKfceC} \% 2 \mathrm{fhZiM} 3 \mathrm{IdC0xPdIzpNb} 7 \mathrm{kcvOVk} \% 2 \mathrm{fWYp} 6 \mathrm{cwSWX}$ HvQae86k4E22Z\%2fuY4BS0Bt0Q7aORLKZQmZ\%2fb77Yjvg6qw\%3d\%3d\&c $\mathrm{rl}=\mathrm{c} \&$ resultLocal=ErrCrlNoResults\&resultNs=Ehost\&crlhashurl=login.aspx\%3fd irect $\% 3$ dtrue $\% 26$ profile $\% 3$ dehost $\% 26$ scope $\% 3$ dsite\%26authtype\%3dcrawler\%2 6jrnl\%3d10895159\%26AN\%3d36459239

Kerckhoffs, A. P., Samsom, M., Rest, M. E. van der, Vogel, J. de, Knol, J., BenAmor, K., Akkermans, L. M. (2009). Lower Bifidobacteria counts in both duodenal mucosa-associated and fecal microbiota in irritable bowel syndrome patients. World Journal of Gastroenterology, 15(23), 2887. https://doi.org/10.3748/wjg.15.2887

Khoshini, R., Dai, S., Lezcano, S., Pimentel, M. (2008). A Systematic Review Of Diagnostic Test For Small Intestinal Bacterial Overgrowth. Digestive Disease and Science, 53, 1443-1454. https://doi.org/10.1007/s10620-007-0065-1

Lacy, B. E., Patel, N. K. (2017). Rome Criteria and a Diagnostic Approach to Irritable Bowel Syndrome. Journal of Clinical Medicine, 6(11), 99. https://doi.org/10.3390/jem6110099

Lammerts van Bueren, A., Mulder, M., Leeuwen, S. (2017). Prebiotic galactooligosaccharides activate mucin and pectic galactan utilization pathways in the human gut symbiont Bacteroides thetaiotaomicron. Scientific Reports, 7(1). https://doi.org/10.1038/srep40478

Lanaspa, M. A., Ishimoto, T., Cicerchi, Ch., Tamura, Y., Roncal-Jimenez, C. A. Chen, W., Tanabe, K., Andres-Hernando, A., Orlicky, D. J., Finol, E., Inaba, S., Li, N., Rivard, J. C., Kosugi, T., Sanchez-Lozada, L. G., Petrash, J. M., Sautin, Y. Y., Ejaz, A. A., Kitagawa, W., Garcia, G. E., Bonthron, D. T., Asipu, A. Diggle, C. P., Rodriguez-Iturbe, B., Nakagawa, T., Johnson, R. (2014). Endogenous Fructose Production and Fructokinase Activation Mediate Rena Injury in Diabetic Nephropathy. In Journal of the American Society of Nephrology, 25(11), 2526-2538. https://doi.org/10.1681/ASN.2013080901

Latulippe, M. E., Skoog, S. M. (2011). Fructose Malabsorption and Intolerance: Effects of Fructose with and without Simultaneous Glucose Ingestion. Critical Reviews in Food Science and Nutrition, 51(7), 583-592. https://doi.org/10.1080/10408398.2011.566646

Le Gall, M., Tobin, V., Stolarczyk, E., Dalet, V., Leturque, A., Brot-Laroche, E. (2007). Sugar sensing by enterocytes combines polarity, membrane bound detectors and sugar metabolism. In Journal of Cellular Physiology, 213(3), 834843. https://doi.org/10.1002/jcp. 21245
Leslie, N. D. (2003). Insights into the Pathogenesis of Galactosemia. Annual review of Nutrition, 23, 59-80. https://doi.org/10.1146/annurev.nutr.23.011702.073135

Li, D.-Y., Yang, M., Edwards, S., Ye, S.-Q. (2013). Nonalcoholic Fatty Liver Disease. Journal of Parenteral and Enteral Nutrition, 37(6), 787793. hppts://doi.org/10.1177/0148607113481623

Lim, I., van Wegen, E., de Goede, C., Deutekom, M., Nieuwboer, A., Willems, A., Kwakkel, G. (2005). Effects of external rhythmical cueing on gait in patients with Parkinson's disease: a systematic review. Clinical Rehabilitation, 19(7), 695 713. https://doi.org/10.1191/0269215505cr906oa

Losurdo, G., Principi, M., Iannone, A., Amoruso, A., Ierardi, E., Di Leo, A., Barone, M. (2018). Extra-intestinal manifestations of non-celiac gluten sensitivity: An expanding paradigm. World journal of gastroenterology, 24(14), 1521-1530. https://doi.org/10.3748/wjg.v24.i14.1521

Macario, E. C., Macario, A. J. L. (2009). Methanogenic archaea in health and disease: A novel paradigm of microbial pathogenesis. International Journal of $\begin{array}{lll}\text { Medical } & \text { Microbiology, 299(2), 99-108. }\end{array}$ https://doi.org/10.1016/j.ijmm.2008.06.011

Macdonald, I. (2003). CARBOHYDRATES - Metabolism of Sugars. Encyclopedia od Food Sciences and Nutrition (Second Edition), 889-891. https://doi.org/10.1016/B0-12-227055-X/00170-X

Mackie, R. I., Sghir, A., Gaskins, H. R. (1999). Developmental microbial ecology of the neonatal gastrointestinal tract. The American Journal of Clinical Nutrition 69(5), 1035-1045. https://doi.org/10.1093/ajcn/69.5.1035s

Magee, A. I. (2000). Metabolic Labeling of Prenyl and Carboxyl-Methyl Groups. Current Protocols in Cell Biology, 5(1). https://doi.org/10.1002/0471143030.cb0705s05

Manolescu, A. R., Augistin, R., Moley, K., Cheeseman, C. (2007). A highly conserved hydrophobic motif in the exofacial vestibule of fructose transporting SLC2A proteins acts as a critical determinant of their substrate selectivity. Molecular Membrane Biology, 24(5-6), 455-463. https://doi.org/10.1080/09687680701298143

Mao, B., Tang, H., Gu, J.,Li, D., Cui, S., Zhao, J., Zhang, H., Chen, W. (2018). In vitro fermentation of raffinose by the human gut bacteria. Food and Function, 9(11), 5824-5831. https://doi.org/10.1039/c8fo01687a

Marquet, P., Duncan, S. H., Chassard, C., Bernalier-Donadille, A., Flint. H. J. (2009). Lactate has the potential to promote hydrogen sulphide formation in the human colon, FEMS Microbiology Letters, 299(2), 128 134. https://doi.org/10.1111/j.1574-6968.2009.01750.x

Marsh, A., Eslick, E. M., Eslick, G. D. (2015). Does a diet low in FODMAPs reduce symptoms associated with functional gastrointestinal disorders? A comprehensive systematic review and meta-analysis. European Journal of Nutrition, 55(3), 897-906. https://doi.org/10.1007/s00394-015-0922-1

Martens, E. C., Kelly, A. G., Tauzin, A. S., Brumer, H. (2014). The Devil Lies in the Details: How Variations in Polysaccharide Fine-Structure Impact the Physiology and Evolution of Gut Microbes. Journal of Molecular Biology, 426(23), 3851-3865. https://doi.org/10.1016/j.jmb.2014.06.022

Mazmanian, S., Round, J., Kasper, D. (2008). A microbial symbiosis factor prevents intestinal inflammatory disease. Nature 453, 620-625. https://doi.org/10.1038/nature07008

Medeiros, F., Casanova, M. A., Fraulob, J. C., Trindade, M. (2012). How Can Diet Influence the Risk of Stoke? International Journal of Hypertension, 2012, 7. https://doi.org/10.1155/2012/763507

Mihajlovski, A., Alric, M., Brugère, J. (2008). A putative new order of methanogenic Archaea inhabiting the human gut, as revealed by molecular analyses of the mcrA gene, Research in Microbiology, 159(7-8), 516-521. https://doi.org/10.1016/j.resmic.2008.06.007

Miller, T., Wolin, M. J. (1983). Interactions of microbial populations in cellulose fermentation. Europe PMC, 42(1), 109-113. https://doi.org/10.1016/b978-0-12341280-5.50013-6

Million, M., Tidjani Alou, M., Khelaifia, S. (2016). Increased Gut Redox and Depletion of Anaerobic and Methanogenic Prokaryotes in Severe Acute Malnutrition. Scientific Reports, 6(1). https://doi.org/10.1038/srep26051

Mohnen, D. (2008). Pectin structure and biosynthesis. Current opinion in plant biology, 11(3), 266-277. https://doi.org/10.1016/j.pbi.2008.03.006

Morrison, D. J., Preston, T. (2016). Formation of short chain fatty acids by the gut microbiota and their impact on human metabolism. Gut Microbes, 7(3), 189-200. https://doi.org/10.1080/19490976.2015.1134082

Mousa, A. A., Rajabi, M. (2017). The Role of Angiogenesis in Cancer Treatment. Biomedicines, 5(2), 34. https://doi.org/10.3390/biomedicines5020034

Moss, A. R., Jouany, J., Newbold, J. (2000). Methane production by ruminants: its contribution to global warming. Animal Research, 49(3), 231-253. https://doi.org/10.1051/animres:2000119

Mussatto, S. I., Mancilha, I. M. (2007). Non-digestible oligosaccharides: A review. $\begin{array}{llll}\text { Carbohydrate } & \text { Polymers, } & 68(3), & 587-597 .\end{array}$ https://doi.org/10.1016/j.carbpol.2006.12.011

Nagao-Kitamoto, H., Kitamoto, S., Kuffa, P., Kamada, N. (2016). Pathogenic role of the gut microbiota in gastrointestinal diseases. Intestinal research, 14(2), 127138. https://doi.org/10.5217/ir.2016.14.2.127

Nakamura, N., Lin, H. C., McSweeney, C. S., Mackie, R. I., Gaskins, H. R. (2010) Mechanisms of Microbial Hydrogen Disposal in the Human Colon and 
Implications for Health and Disease. Food Science and Technology, 1, 363-395. https://doi.org/10.1146/annurev.food.102308.124101

Nava, G., Carbonero, F., Croix, J., Greenberg, E., Gaskins, H. R. (2012) Abundance and diversity of mucosa-associated hydrogenotrophic microbes in the healthy human colon. ISME

Journal, 6, 57-70.

https://doi.org/10.1038/ismej.2011.90

Nelis, G. F., Vermeeren, M. A. P., Jansen, W. (1990). Role of fructose-sorbitol malabsorption in the irritable bowel syndrome. Gastroenterology, 99(4), 10161020. https://doi.org/10.1016/0016-5085(90)90621-7

Nookaraju, A., Upadhyaya, C. P., Pandey, S. K., Young, K. E., Hong, S. J., Park, S. K., Park, S. W. (2010). Molecular approaches for enhancing sweetness in fruits and vegetables. Scientia Horticulturae, 127(1),

$1-15$. https://doi.org/10.1016/j.scienta.2010.09.014

O'Hara, A. M., Shanahan, F. (2006). The gut flora as a forgotten organ. EMBO report, 7 (7), 688-693. https://doi.org/10.1038/sj.embor.7400731

Ong, K. D., Mitchell, S. B., Barrett, J. S., Shepherd, S. J., Irving, P. M., Biesierski, J. R., Smith, S., Gibson, P. R., Muir, J. G. (2010). Manipulation of dietary short chain carbohydrates alters the pattern of gas production and genesis of symptoms in irritable bowel syndrome. Journal of Gastroenterology and Hepatology, 25(8), 1366-1373. https://doi.org/10.1111/j.1440-1746.2010.06370.x

Ortega-González, M., Ocón, B., Romero-Calvo, I., Anzola, A., Guadix, E., Zarzuelo, A., Martínez-Augustin, O. (2013). Nondigestible oligosaccharides exert nonprebiotic effects on intestinal epithelial cells enhancing the immune response via activation of TLR4-NFkB. Molecular Nutrition \& Food Research, 58(2), 384 393. https://doi.org/10.1002/mnfr.201300296

Orth, J. D., Conrad, T. M., Na, J., Lerman, J. A., Nam, H., Feist, A. M., Palsson, B. (2011). A comprehensive genome-scale reconstruction of tilg metabolism. EMBO report, 7, 535. https://doi.org/10.1038/msb.2011.65

Papagianni, M., Anastasiadou, S. (2009). Pediocins: The bacteriocins of Pediococci. Sources, production, properties and applications. Microbial Cell Factories 8(1), 3. https://doi.org/10.1186/1475-2859-8-3

Pascual, J. M. (2008). Metabolic Diseases of The Nervous System. Molecular Neurology, 149-161. https://doi.org/10.1016/B978-012369509-3.50012-3

Payne, A. N., Chassard, C., Lacroix, C. (2012). Gut microbial adaptation to dietary consumption of fructose, artificial sweeteners and sugar alcohols: implications for host-microbe interactions contributing to obesity. Obesity Reviews, 13(9), 799809. https://doi.org/10.1111/j.1467-789X.2012.01009.x

Petera, B., Delattre, C., Pierre, G., Wadouachi, A., Elboutachfaiti, R., Engel, E., Fenoradosoa, T. A. (2015). Characterization of arabinogalactan-rich mucilage from Cereus triangularis cladodes. Carbohydrate Polymers, 127, 372380. https://doi.org/10.1016/j.carbpol.2015.04.001

Peters, D. (2006). Carbohydrates for fermentation. Biotechnology Journal, 1(7-8), 806-814. https://doi.org/10.1002/biot.200600041

Peters, S. L., Biesiekierski, J. R., Yelland, G. W., Muir, J. G., Gibson, P. R. (2014) Randomised clinical trial: gluten may cause depression in subjects with noncoeliac gluten sensitivity-an exploratory clinical study. Alimentary pharmacology \& therapeutics, 39(10), 1104-1112. https://doi.org/10.1111/apt.12730

Pimentel, D., Berger, B., Filiberto, D., Newton, M., Wolfe, B., Karabinakis, E., Clark, S., Poon, E., Abbett, E., Nandagopal, S. (2004). Water Resources: Agricultural and Environmental Issues, BioScience, 54(10), 909918. https://doi.org/10.1641/0006-3568(2004)054[0909:WRAAEI]2.0.CO;2 Pinchuk, I., Bressollier, V., Fenet, B., Sorokulova, I. B., Megraud, F., Urdaci, M. (2020). In Vitro Anti-Helicobacter pylori Activity of the Probiotic Strain Bacillus subtilis 3 Is Due to Secretion of Antibiotics. Antimicrobial Agents and Chemotherapy, 45(11), 3156-3161. https://doi.org/10.1128/AAC.45.11.31563161.2001

Posserud, I., Stotzer, P., Björnsson, E. S., Abrahamsson, H., Simrén, M. (2007). Small intestinal bacterial overgrowth in patients with irritable bowel syndrome Gut Microbionta, 56, 802-808. https://gut.bmj.com/content/56/6/802

Prakash, D., Upadhyay, G., Pushpangadan, P., Gupta, C. (2011). Antioxidant and Free Radical Scavenging Activities of Some Fruits. Journal of Complementary and Integrative Medicine, 8(1), 1-16. https://doi.org/10.2202/1553-3840.1513

Qi, X., Tester, R. F. (2019). Fructose, galactose and glucose - In health and disease. Clinical Nutrition ESPEN, 33, 18-28. https://doi.org/10.1016/j.clnesp.2019.07.004 Qin, J., Li, R., Raes, J., Arumugam, M., Burgdorf, K. S., Manichanh, Ch., Nielsen, T., Pons, N., Levenez, F., Yamada, T., Mende, D. R., Li, J., Xu, J., Li, D., Cao, J., Wang, B., Liang, H., Zheng, H., Xie, Y., Tap, J., Lepage, P., Bertala, M., Batto, J. Hansen, T., Paslier, D., Linneberg, A., Nielsen, H. B., Pelletier, E., Bork, P. (2010). A human gut microbial gene catalogue established by metagenomic sequencing. Nature, 464, 59-65. https://doi.org/10.1038/nature08821

Rao, S. S. C., Yu, S., Fedewa, A. (2015). Systematic review: dietary fibre and FODMAP-restricted diet in the management of constipation and irritable bowe syndrome. Alimentary Pharmacology and Therapeutics, 41(12), 12561270. https://doi.org/10.1111/apt.13167

Rastall, R. A. (2010). Functional Oligosaccharides: Application and Manufacture. Annual Review of Food Science and Technology, 1(1), 305339. https://doi.org/10.1146/annurev.food.080708.1

Rea, M., Sit, C. S., Clayton, E., O'Connor, P. M., Whittal, R. M., Zheng, J., Vederas, J. C., Ross, R. P., Hill, C. (2010). Thuricin CD, a posttranslationally modified bacteriocin with a narrow spectrum of activity against Clostridium difficile. Proceedings of the National Academy of Sciences May 2010, 107(20), 9352-9357. https://doi.org/10.1073/pnas.0913554107

Riby, E., Fujisawa, T., Kretchmer, N. (1993). Fructose absorption, The American Journal of Clinical Nutrition, 58(5), 748753. https://doi.org/10.1093/ajcn/58.5.748S

Ritsema, T., Smeekens, S. (2003). Fructans: beneficial for plants and humans. Current Opinion in Plant Biology, 6(3), 223-230. https://doi.org/10.1016/s13695266(03)00034-7

Rivière, A., Selak, M., Lantin, D., Leroy, F., Vuyst, L. (2016). Bifidobacteria and Butyrate-Producing Colon Bacteria: Importance and Strategies for Their Stimulation in the Human Gut. Frontiers in Microbiology, 7. https://doi.org/10.3389/fmicb.2016.00979

Roberfroid, M. (2007). Prebiotics: The Concept Revisited, The Journal of Nutrition, 137(3), 830-837. https://doi.org/10.1093/jn/137.3.830S

Roberfroid, M. B. (1999). Concepts in Functional Foods: The Case of Inulin and Oligofructose. The Journal of Nutrition, 129(7), 1398S1401S. https://doi.org/10.1093/jn/129.7.1398S

Roberfroid, M. B., Delzenne, N. M. (1998). DIETARY FRUCTANS. Annual Review of Nutrition, 18(1), 117-143. https://doi.org/10.1146/annurev.nutr.18.1.117

Roberfroid, M., Gibson, G., Hoyles, L., McCartney, A., Rastall, R., Rowland, I., Meheust, A. (2010). Prebiotic effects: Metabolic and health benefits. British Journal of Nutrition, 104(2), 1-63. https://doi.org/10.1017/S0007114510003363 Röder, P. V., Geillinger, K. E., Zietek, T. S., Thorens, B., Koepsell, H., Daniel, H (2014). The Role of SGLT1 and GLUT2 in Intestinal Glucose Transport and Sensing. PLoS ONE, 9(2). https://doi.org/10.1371/journal.pone.0089977

Round, J. L., Lee, S. M., Li, J., Tran, G., Jabri, B., Chatila, T., Mazmanian, S. (2011). The Toll-Like Receptor 2 Pathway Establishes Colonization by a Commensal of the Human Microbiota. Science, 322(6032), 974-977. https://doi.org/10.1126/science.1206095

Routy, B., Chatelier, E., Derosa, L., Duong, C. P. M., Alou, M. T., Daillere, R., Fluckiger, A., Messaoudene, M., Rauber, C., Zitvogel, L. (2018). Gut microbiome influences efficacy of PD-1-based immunotherapy against epithelial tumors. Science, 359(6371), 91-97. https://doi.org/10.1126/science.aan3706

Rumessen, J. J., Gudmand-Høyer, E. (1988). Functional Bowel Disease: Malabsorption and Abdominal Distress After Ingestion of Fructose, Sorbitol, and Fructose- Sorbitol Mixtures. Gastroenterology, 95(3), 694-700. https://doi.org/10.1016/S0016-5085(88)80016-7

Sachdev, A. H., Pimentel, M. (2013). Gastrointestinal bacterial overgrowth: pathogenesis and clinical significance. Therapeutic Advances in Chronic Diseas, 4(5), 233-231. https://doi.org/10.1177/2040622313496126

Salminen, S., Salminen, E., Bridges, J., Marks, V. (1986). The effects of sorbitol on the gastrointestinal microflora in rats. Zeitschrift Für Ernährungswissenschaft, 25(2), 91-95. https://doi.org/10.1007/BF02020738

Salonen, A., Lahti, L., Salojärvi, J. Holtrop, G., Korpela, K., Duncan, S., Date, P., Ferquharson, F., Johnstone, A. M., Lobley, G. E., Louis, P., Flint, H. J., Vos, W. M. (2014). Impact of diet and individual variation on intestinal microbiota composition and fermentation products in obese men. The ISME Journal 8, 22182230 (2014)._https://doi.org/10.1038/ismej.2014.63

Sangwan, V., Tomar, S. K., Singh, R. R. B., Singh, A. K., Ali, B. (2011). Galactooligosaccharides: Novel Components of Designer Foods. Journal of Food Science, 76(4), 103-111. https://doi.org/10.1111/j.17503841.2011.02131.X

Sanz, Y., Nadal, I., Sanchez, E. (2005). Probiotics as Drugs Against Human Gastrointestinal Infections. Recent Patents on Anti-Infective Drug Discovery, 2(2), 148-156. https://doi.org/10.2174/157489107780832596

Sarbini, S. R., Rastall, R. A. (2011). Prebiotocs: Metabolism, Structure, and Function. Functional Food Reviews, 3(3), 93-106. https://doi.org/10.2310/6180.2011.00004

Sarmiento-Rubiano, L. A., Zúñiga, M., Pérez-Martínez, G., Yebra, M. J. (2007). Dietary supplementation with sorbitol results in selective enrichment of lactobacilli in rat intestine. Research in Microbiology, 158(8-9), 694 701. https://doi.org/10.1016/j.resmic.2007.07.007

Scanlan, P., Marchesi, J. (2008). Micro-eukaryotic diversity of the human distal gut microbiota: qualitative assessment using culture-dependent and -independent analysis of faeces. The ISME Journal, 2, 1183-1193. https://doi.org/10.1038/ismej.2008.76

Scott, K. P., Gratz, S. W., Sheridan, P. O., Flint, H. J., Duncan, S. H. (2013). The influence of diet on the gut microbiota. Pharmacological Research, 69(1), 52-60. https://doi.org/10.1016/j.phrs.2012.10.020

Shepherd, S. J., Gibson, P. R. (2006). Fructose Malabsorption and Symptoms of Irritable Bowel Syndrome: Guidelines for Effective Dietary Management. Journal of the American Dietetic Association, 106(10), 1631-1639. https://doi.org/10.1016/j.jada.2006.07.010

Shepherd, S., Parker, F., Muir, J., Gibson, P. (2008). Dietary Triggers of Abdominal Symptoms in Patients With Irritable Bowel Syndrome: Randomized Placebo-Controlled Evidence. Clinical Gastroenterology and Hepatology, 6(7), 765-771. https://doi.org/10.1016/j.cgh.2008.02.058

Schalkwijk, C. G., Stehouwer, C. D. A., Hinsbergh, V. W. M. (2004). Fructosemediated non-enzymatic glycation: sweet coupling or bad modification. Diabetes Metabolism Research and Reviews, 20(5), 369382. https://doi.org/10.1002/dmrr.488 
Skoog, S. M., Bharucha, A. E. (2004). Dietary Fructose and Gastrointestinal Symptoms: A Review. The American Journal of Gastroenterology, 99(10), 20462050. https://doi.org/10.1111/j.1572-0241.2004.40266.x

Sonnenburg, J., Bäckhed, F. (2016). Diet-microbiota interactions as moderators of human metabolism. Nature 535, 56-64. https://doi.org/10.1038/nature18846 Spiller, R., Garsed, K. (2009). Postinfectious Irritable Bowel Syndrome. Gastroenterology, 136(6),

1979-1988. https://doi.org/10.1053/j.gastro.2009.02.074

Staudacher, H. M., Lomer, M. C. E., Anderson, J. L., Barrett, J. S., Muir, J. G. Irving, P. M., Whelan, K. (2012). Fermentable Carbohydrate Restriction Reduces Luminal Bifidobacteria and Gastrointestinal Symptoms in Patients with Irritable Bowel Syndrome. The Journal of Nutrition, 142(8), 1510-1518. https://doi.org/10.3945/jn.112.159285

Staudacher, H. M., Whelan, K. (2016). Altered gastrointestinal microbiota in irritable bowel syndrome and its modification by diet: probiotics, prebiotics and the low FODMAP diet. Proceedings of the Nutrition Society, 75(03), 306-318. https://doi.org/10.1017/s0029665116000021

Staudacher, H., Irving, P., Lomer, M. (2014). Mechanisms and efficacy of dietary FODMAP restriction in IBS. Nature Reviews Gastroenterology Hepatology, 11, 256-266. https://doi.org/10.1038/nrgastro.2013.259

Steggerda, F. R., Richards, E. A., Rackis, J. J. (1966). Effects of Various Soybean Products on Flatulence in the Adult Man. Experimental Biology and Medicine, 121(4), 1235-1239. https://doi.org/10.3181/00379727-121-31014

Symons, P., Jones, M. P., Kellow, J. E. (1992). Symptom Provocation in Irritable Bowel Syndrome Effects of Differing Doses of Fructose-Sorbitol. Scandinavian Journal of Gastroenterology, 27(11), 940-944 https://doi.org/10.3109/00365529209000167

Tanaka, L. Y. A., de Oliveira, A. J. B., Gonçalves, J. E., Cipriani, T. R., de Souza L. M., Marques, M. C. A., Iacomini, M. (2010). An arabinogalactan with anti-ulcer protective effects isolated from Cereus peruvianus. Carbohydrate Polymers, 82(3), 714-721. https://doi.org/10.1016/j.carbpol.2010.05.043

Tanisho, S., Ishiwata, Y. (1994). Continuous hydrogen production from molasses by the bacterium Enterobacter aerogenes. International Journal of Hydrogen Energy, 19(10), 807-812. https://doi.org/10.1016/0360-3199(94)90197-X

Tanisho, S., Suganuma, T. (1999). Feasibility of hydrogen production from seaweeds by fermentation; Kaiso wo kishitsu ni riyoshita hakoho ni yoru suiso seisan no kanosei ni tsuite. Suiso Enerugi Shisutemu. .Journal of the Hydrogen Energy Systems Society of Japan, 24(1), 19-24. https://www.osti.gov/etdeweb/biblio/20012351

Tilg, H., Kaser, A. (2011). Gut microbiome, obesity, and metabolic dysfunction. The Journal of Clinical Investigation, 121(6), 2126-2132. https://doi.org/10.1172/JCI58109

Tojo, R., Suárez, A., Clemente, M. G., de los Reyes-Gavilán, C. G., Margolles, A., Gueimonde, M., Ruas-Madiedo, P. (2014). Intestinal microbiota in health and disease: role of bifidobacteria in gut homeostasis. World journal of gastroenterology, 20(41),

https://doi.org/10.3748/wjg.v20.i41.15163

Tuck, C. J., Muir, J. G., Barret, J. S., Gibson, P. R. (2014). Fermentable oligosaccharides, disaccharides, monosaccharides and polyols: role in irritable bowel syndrome. Gastroenterology and Hepatology, 8(7), 819-834. https://doi.org/10.1586/17474124.2014.917956

Turnbaugh, P. J., Gordon, J. I. (2009). The core gut microbiome, energy balance and obesity. The Journal of Physiology, 587(17), 4153 4158. https://doi.org/10.1113/jphysiol.2009.174136

Turnbaugh, P. J., Quince, C., Faith, J. J., McHardy, A. C., Yatsunenko, T., Niazi, F., Gordon, J. I. (2010). Organismal, genetic, and transcriptional variation in the deeply sequenced gut microbiomes of identical twins. Proceedings of the National $\begin{array}{llll}\text { Academy of } & \text { Sciences, } & \text { 107(16), }\end{array}$ 7508. https://doi.org/10.1073/pnas.1002355107

Turner, S. R., Love, R. M., Lyons, K. M. (2004). An in-vitro investigation of the antibacterial effect of nisin in root canals and canal wall radicular dentine International Endodontic Journal, 37(10), 664 671. https://doi.org/10.1111/j.1365-2591.2004.00846.x

Van Loo, J., Coussement, P., De Leenheer, L., Hoebregs, H., Smits, G. (1995). On the presence of Inulin and Oligofructose as natural ingredients in the western diet. Critical Reviews in Food Science and Nutrition, 35(6), 525-552. https://doi.org/10.1080/10408399509527714

Ventura, E. E., Davis, J. N., Goran, M. I. (2012). Sugar Content of Popular Sweetened Beverages Based on Objective Laboratory Analysis: Focus on Fructose $\begin{array}{llll}\text { Content. The } & \text { Obesity }\end{array}$ 874. https://doi.org/10.1038/oby.2010.255

Vernia, P., Marcheggiano, A., Caprilli, R., Frieri, G., Corrao, G., Valpiani, D., Di Paolo, M. C., Paoluzi, P., Torsoli, A. (1995). Short-chain fatty acid topical treatment in distal ulcerative colitis. Alimentary Pharmacology \& Therapeutics, 9(3), 309-313. https://doi.org/10.1111/j.1365-2036.1995.tb00386.x

Viuda-Martos, M., Ruiz-Navajas, Y., Fernández-López, J., Pérez-Álvarez, J. A (2008). Functional Properties of Honey, Propolis, and Royal Jelly. Journal of Food Science, 73(9), 117-124. https://doi.org/10.1111/j.1750-3841.2008.00966.x Wampach, L., Heintz-Buschart, A., Hogan, A., Muller, E. E. L., Narayanasamy, S., Laczny, C. C., Hugerth, L. W., Bindl, L., Bottu, J., Andersson, A. F., Beaufort, C., Wilmes, P. (2017). Colonization and Succession within the human gut microbiome by Archea, Bacteria, and microeukaryotes during the first year of life. Food Microbiology, 8. https://doi.org/10.3389/fmicb.2017.00738

Wang, H., Shi, S., Bao, B., Li, X., Wang, S. (2015). Structure characterization of an arabinogalactan from green tea and its anti-diabetic effect. Carbohydrate Polymers, 124, 98-108. https://doi.org/10.1016/j.carbpol.2015.01.070_

Wang, Y., Guo, Q., Goff, H. D., LaPointe, G. (2019). Oligosaccharides: Structure, Function and Application. Encyclopedia of Food Chemistry, 1, 202-207. https://doi.org/10.1016/B978-0-08-100596-5.21585-0

Wolf, P. G., Biswas, A., Morales, S. E., Greening, C., Gaskins, H. R. (2016). H metabolism is widespread and diverse among human colonic microbes. Gut microbes, 7(3), 235-245. https://doi.org/10.1080/19490976.2016.1182288

Wong, J. M. W., de Souza, R., Kendall, C. W. C., Emam, A. Jenkins, D. J. A. (2006). Colonic Health: Fermentation and Short Chain Fatty Acids. Journal of Clinical Gastroenterology, 40(3), 235-243. https://doi.org/10.1097/00004836.200603000-00015

Wright, G., Higgin, J. J., Raines, R. T., Steenbergen, Ch., Murphy, E. (2003). Activation of the Prolyl Hydroxylase Oxyge-sensor Results in Induction of GLUT1, Heme Oxygenase-1, and Nitric-oxide Synthase Proteins and Confers Protection from Metabolic Inhibition to Cardiomyocytes. Journal of Biological Chemistry, 278(22), 20235-20239. http://doi.org/10.1074/jbc.M301391200

Xiong, L., Wang, Y., Gong, X. (2017). Prevalence of lactose intolerance in patients with diarrhea-predominant irritable bowel syndrome: data from a tertiary center in southern China. Journal o Health, Population and Nutrition, 36(1), 38 https://doi.org/10.1186/s41043-017-0113-1

Yang, J., Liang, L., Li, J., Zhang, K.-Q. (2013). Nematicidal enzymes from microorganisms and their applications. Applied Microbiology and Biotechnology, 97(16), 7081-7095. https://doi.org/10.1007/s00253-013-5045-0

Yapo, B. M. (2011). Rhamnogalacturonan-I: A Structurally Puzzling and Functionally Versatile Polysaccharide from Plant Cell Walls and Mucilages.

Polymer

Reviews, 51(4),

$391-$

413. https://doi.org/10.1080/15583724.2011.615962

Yin, J., Yang, G., Wang, S., Chen, Y. (2006). Purification and determination of stachyose in Chinese artichoke (Stachys Sieboldii Miq.) by high-performance liquid chromatography with evaporative light scattering detection. Talanta, 70(1), 208-212. https://doi.org/10.1016/j.talanta.2006.03.027

Yracheta, J. S., Lanaspa, M. A., Le, M., Abdelmalak, M. F., Alfonso, J., SánchezLozada, L. G., Johnson, R. J. (2015). Diabetes and Kidney Disease in American Indians: Potential Role of Sugar-Sweetened Beverages. Mayo Clinic Proceedings 90(6), 813-823. https://doi.org/10.1016/j.mayocp.2015.03.018

Zheng, X., Chu, H., Cong, Y., Deng, Y., Long, Y., Zhu, Y., Pohl, D., Fried, M., Dal, N., Fox, M. (2015). Self-reported lactose intolerance in clinic patients with functional gastrointestinal symptoms: prevalence, risk factors, and impact on food choices. Neurogastroenterology \& Motility, 27(8), 1138 1146. https://doi.org/10.1111/nmo.12602

Zvanych, R., Lukenda, N., Kim, J., Li, X., Petrof, E., Khan, W. (2014). Small molecule immunomodulins from cultures of the human microbiome member Lactobacillus plantarum. The Journal of Antibiotics, 67, 85-88. https://doi.org/10.1038/ja.2013.126

Zykwinska, A., Boiffard, M. H., Kontkanen, H., Buchert, J., Thibault, J. F., Bonnin, E. (2008). Extraction of Green Labeled Pectins and Pectic Oligosaccharides from Plant Byproducts. Journal of Agricultural and Food Chemistry, 56(19), 8926-8935. https://doi.org/10.1021/jf801705a 